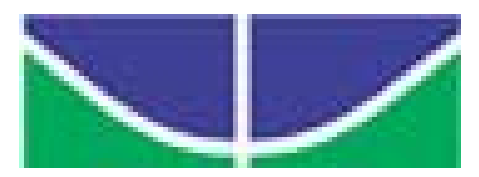

UNIVERSIDADE DE BRASÍLIA

Centro de Excelência em Turismo

\title{
A (IN) SUSTENTABILIDADE DO ECOTURISMO NO ATRATIVO NATURAL FAZENDA POÇO AZUL - DF
}

\author{
Cédric Bainy Valente
}

Orientadora: Iara Brasileiro

Monografia apresentada ao Centro de Excelência em Turismo da Universidade de Brasília como requisito parcial para a obtenção do certificado de Especialista em Gestão de Negócios em Turismo. 
UNIVERSIDADE DE BRASÍLIA

Centro de Excelência em Turismo

Curso de Especialização em Gestão de Negócios em Turismo

\title{
A (IN) SUSTENTABILIDADE DO ECOTURISMO NO ATRATIVO NATURAL FAZENDA POÇO AZUL - DF
}

\author{
Cédric Bainy Valente
}

Banca Examinadora

Iara Brasileiro, Doutora

Orientadora

Membro da Banca

Brasília, DF, 30 de Maio de 2005 


\section{A (IN) SUSTENTABILIDADE DO ECOTURISMO NO ATRATIVO NATURAL FAZENDA POÇO AZUL - DF}

Comissão Avaliadora

Professora Orientadora Iara Brasileiro

Professor (a)

Professor (a) 
Dedico essa monografia aos meus pais, familiares, amigos, professores e a minha namorada Naiara Betânia de Paiva Correa. 
Agradeço, muito especialmente, aos meus pais que sempre me incentivaram a buscar os meus ideais; a minha tia Litz Mary Lima Bainy que muito me apoiou nas pesquisas e na elaboração dessa monografia; aos meus irmãos; a minha namorada Naiara Betânia de Paiva Correa pelo carinho e compreensão, entendendo que precisava investir no meu aperfeiçoamento profissional; e aos professores do curso, em especial, a professora Iara Brasileiro, que dividiram seus conhecimentos e contribuíram para o meu aprendizado e aperfeiçoamento, aos quais eu gostaria de deixar a seguinte mensagem: A semente que foi plantada, crescerá e se transformará em uma grande árvore que dará bons frutos e novas sementes. Muito Obrigado. 


\section{RESUMO}

A (in)sustentabilidade do ecoturismo no atrativo natural Fazenda Poço Azul - DF é constatada a partir da análise da infra-estrutura existente, da forma como é utilizado, dos serviços disponibilizados e do levantamento por amostragem do perfil, dos anseios e da visão dos visitantes em relação ao atrativo. A análise baseia-se nos conteúdos bibliográficos pesquisados, culminando para apresentação de propostas de adequação que atendam aos princípios básicos de sustentabilidade.

Palavras-chave: Ecoturismo, Sustentabilidade e Fazenda Poço Azul-DF 


\begin{abstract}
The (in)sustentability of the ecoturism in the natural attractive of Farm Poço Azul - DF is evidenced from the analysis of the existing infrastructure, of the from as it is used, of the availability services and the survey for sampling of the profile, the yearnings and the vision of the visitors in relation to the attractive one. The analysis is based on the searched bibliographical contents, culminating for presentation of adequacy proposals that take care of to the basic principles of sustentability of the tourism.
\end{abstract}

Key-words: Ecoturism, Sustentability and Farm Poço Azul - DF 


\section{SUMÁRIO}

INTRODUÇÃO

\section{CAPÍTULOS}

Pág.

1 - MARCO TEÓRICO 13

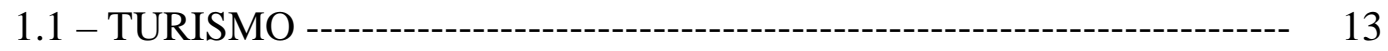

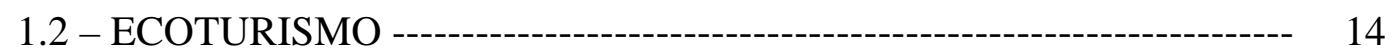

1.3 - EDUCAÇÃO AMBIENTAL E PROCESSOS EDUCATIVOS -------- 17

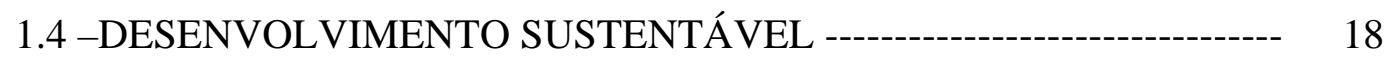

1.5 - PLANEJAMENTO --- 21

2 - METODOLOGIA 23

3- FAZENDA POÇO AZUL 23

3.1- CARACTERIZAÇÃO --- 23

3.1.1- Localização ------------------------------------------------------ 23

3.1.2- Acesso --- 23

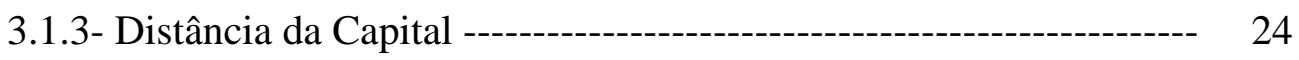

3.1.4- Atrativos Naturais -----_----- 24

3.1.5- Taxa de Visitação ---------------------------------------- 25

3.1.6- Capacidade de Carga ------------------------------------------- 25

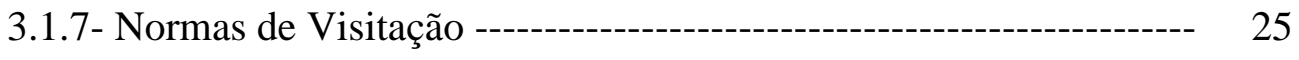

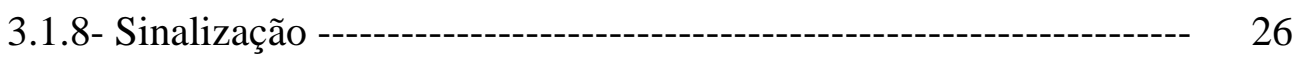

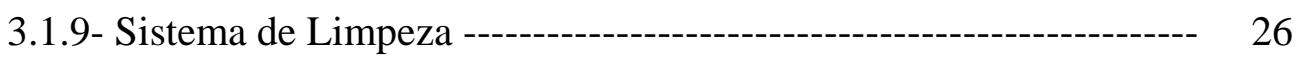

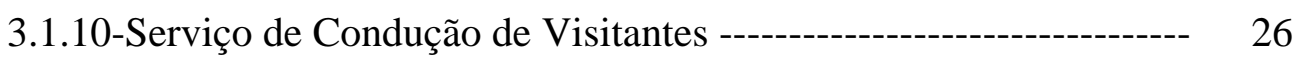

3.1.11- Educação Ambiental ---------------------------------------------- 27

3.1.12- Trilhas --------o--- 27

3.1.13- Equipamentos --------------------------------------------------- 27

3.1.14- Alimentos e Bebidas ---_-_-- 28

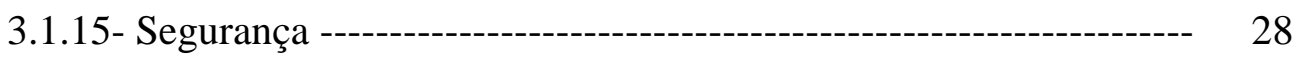

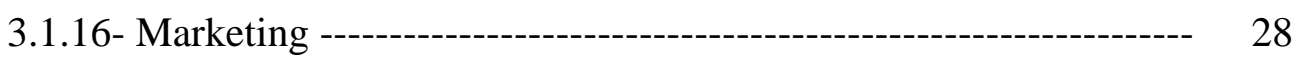

3.1.17- Administração ---_- 28 
$\begin{array}{lr}\text { 3.2- PESQUISA } & 29\end{array}$

3.2.1- Resultados da Pesquisa ------------------------------------------- 30

3.3- PROPOSTAS PARA O DESENVOLVIMENTO DO ECOTURÍSMO

NA FAZENDA POÇO AZUL - DF 47

3.3.1- Acesso ----- 48

3.3.2- Taxa de Visitação -------------------------------------------------------- 48

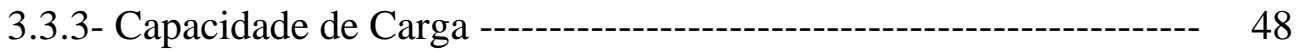

3.3.4- Normas de Visitação ---------------------------------------------------- 48

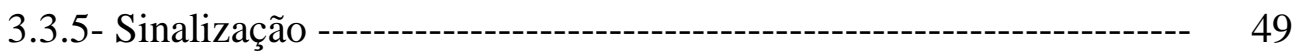

3.3.6- Sistema de Limpeza ----------------------------------------------------- 50

3.3.7- Serviço de Condução de Visitantes --------------------------------- 50

3.3.8- Educação Ambiental --------------------------------------------------- 51

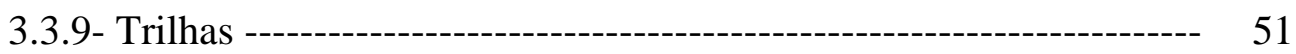

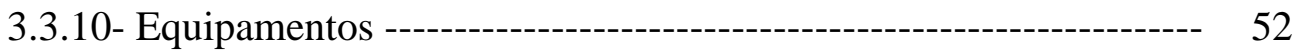

3.3.11- Alimentos e Bebidas -------------------------------------------------- 53

3.3.12- Segurança --------------------------------------------------------------- 53

3.3.13- Marketing --------------------------------------------------------------- 54

3.3.14- Administração ------------------------------------------------------- 54

3.3.15- Centro de Atendimento ao Turista ---------------------------------- 54

3.3.16- Monitoramento e Acompanhamento-------------------------------- 54

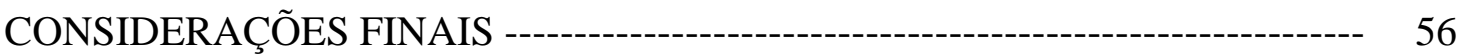

REFERÊNCIA BIBLIOGRÁFICA ------------------------------------------------------- 57

ANEXOS ---------------------------------------------------------------------------------------- 59 


\section{Lista de Ilustrações}

\section{Figuras}

Pág.

Figura 01 - Local de Origem dos Visitantes -------------------------------------------- 31

Figura 02 - Local de Origem dos Visitantes -------------------------------------------- 31

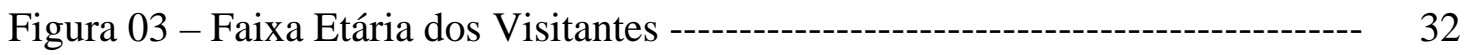

Figura 04 - Nível de Escolaridade dos Visitantes -------------------------------------- 33

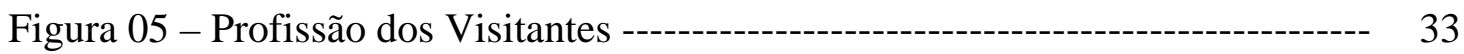

Figura 06 - Renda Mensal dos Visitantes ---------------------------------------------- 34

Figura 07 - Quantidade de Vezes que Visitou o Atrativo ---------------------------- 35

Figura 08 - Os Visitantes Costumam Vir Acompanhados de Quantas Pessoas ---- 35

Figura 09 - A Visita Ocorreu Por Intermédio de Excursão ou Viagem Própria ---- 36

Figura 10 - Meio de Transporte Utilizado Pelo Visitante ----------------------------- 36

Figura 11 - Maneira Pela Qual o Visitante Ficou Sabendo do Atrativo -------------- 37

Figura 12 - O Visitante Considera que o Acesso ao Atrativo está em Boas Condições

Figura 13 - O Visitante Considera a Sinalização (Interna e Externa) do Atrativo

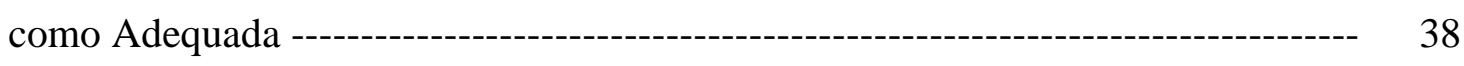

Figura 14 - Deficiências do Atrativo Segundo Visitantes ----------------------------- 39

Figura 15 - O que o Visitante Gosta de Fazer no Atrativo ---------------------------- 40

Figura 16 - O que o Visitante Faz com o Lixo que Produz no Atrativo ------------- 40

Figura 17 - Para o Visitante a Maneira Como são Utilizadas as Cachoeiras Causa Degradação ao Meio Ambiente

Figura 18 - O Visitante se Importaria de Estacionar o Veículo mais Longe para Minimizar o Impacto ao Meio Natural -

Figura 19 - Para o Visitante Seria Melhor se Existisse um Número PréDeterminado de Pessoas Por Cachoeira

Figura 20 - Participaria de Trabalhos de Educação Ambiental (Palestras e 42 Oficinas) no Atrativo

Figura 21 - Deveria ser Construído Um Local Específico Para Churrasco

Figura 22 - Você Já se Machucou Saltando da Cachoeira ou conhece alguém que já 
Figura 23 - Você Participaria de Aulas de Rapel, Escalada, Tirolesa ou Mergulho

Figura 24 - A Obrigatoriedade de Guias Especializados para se Entrar na Fazenda Minimizaria o Impacto dos Turistas sobre o Meio Ambiente

Figura 25 - Você Já Foi Vítima de Assalto ou Furto Dentro do Atrativo

Figura 26 - Qual o Nível de Satisfação que Você Tem com a Infra-Estrutura do

Poço Azul

Figura 27 - Qual o Nível de Satisfação que Você Tem com os Serviços

Disponibilizados no Poço Azul

Figura 28 - Qual o Nível de Satisfação que Você Tem com os Recursos Naturais Existentes na Fazenda Poço Azul - DF 


\section{INTRODUÇÃO}

O turismo em áreas naturais surge como um fenômeno social oriundo de uma situação de crise ambiental que eclodiu nas sociedades modernas onde a natureza, que era objeto de apropriação e exploração, passa a ser valorada diante da escassez de recursos naturais. Com isso, os espaços naturais tornam-se um novo objeto de desejo do viajante, proporcionando mudanças de paradigma, onde a natureza inóspita, assustadora e selvagem passa a ter uma caráter acolhedor e atraente.

Diante dessa tendência, o mercado turístico observa uma nova oportunidade de negócio onde "a natureza atraente” se transforma em uma mercadoria turística, originando um novo segmento chamado ecoturismo.

O ecoturismo tem a natureza como uma mercadoria natural que não é socialmente produzida e, portanto deve ser conservada, mantida ou incrementada. Contudo, esse segmento também possui um caráter econômico que utiliza a mercadoria “natureza” de forma massificada em busca de um grande retorno financeiro, o que pode proporcionar uma relação não harmoniosa entre o homem e a natureza, provocando grandes impactos ambientais e uma modificação do meio natural.

Observa-se que a sustentabilidade depende do equilíbrio entre os aspectos ecológicos, culturais, sociais e econômicos. Diante dos fatos, surge a percepção de que o ecoturismo apresenta um potencial para proteger e, ao mesmo tempo, para desestruturar o patrimônio natural e cultural, onde instrumentos como planejamento e educação ambiental possuem capacidade de minimizar os impactos negativos provocados pela atividade junto a esses patrimônios.

O Brasil, indiscutivelmente, possui um grande potencial a ser trabalhado pelo segmento de ecoturismo, onde sua biodiversidade, suas riquezas paisagísticas, seu patrimônio natural, suas peculiaridades culturais e a criatividade do povo fazem com que seja reconhecido internacionalmente. 
A região do Distrito Federal e entorno possui uma grande diversidade de atrativos naturais, que em sua maioria não desenvolvem um trabalho efetivo de planejamento sustentável que vise à exploração consciente dos recursos disponíveis, apesar de já receberem uma demanda considerável de visitantes da própria região.

É o caso que ocorre com o atrativo natural Fazenda Poço Azul, localizado em uma propriedade privada do município de Brazlândia - DF a 48 km de Brasília, que está aberto a visitação mediante o pagamento de uma taxa e que possui um conjunto de elementos que fazem com que tenha um enorme potencial turístico a ser desenvolvido pelo segmento de ecoturismo.

Como o potencial turístico do referido atrativo ocupa-se de recursos naturais extremamente frágeis e com a grande preocupação em conservá-lo, observa-se a necessidade da realização de um planejamento capaz de organizar o desenvolvimento da atividade turística de forma a atender as expectativas e desejos dos turistas, aos objetivos empresariais do proprietário e, ao mesmo tempo, minimizar os impactos provocados pela atividade no meio natural.

Com intuito de contribuir para que a atividade turística no atrativo natural Fazenda Poço Azul possa ocorrer de forma organizada e buscando atender os princípios de sustentabilidade, o presente trabalho analisa a oferta turística existente no atrativo a partir de referencial bibliográfico e, no final, apresenta sugestões de planejamento que possam colaborar para o adequado desenvolvimento do ecoturismo.

Para elaboração deste trabalho foram realizadas pesquisas empíricas in loco, pesquisas e leituras bibliográficas e experiências já vivenciadas.

Esta monografia é apresentada em três capítulos. O primeiro apresenta a fundamentação teórica do trabalho, o segundo apresenta a metodologia utilizada e o terceiro apresenta a caracterização da Fazenda Poço Azul, a pesquisa realizada com seus visitantes e as sugestões de propostas para o desenvolvimento sustentável do turismo local. 


\section{1 - MARCO TEÓRICO}

\section{1 - TURISMO}

O Turismo é um fenômeno social que consiste no deslocamento voluntário e temporário de indivíduos ou grupos de pessoas que, por motivos de descanso, recreação, lazer, cultura, educação, saúde e negócio, saem de seu local de residência habitual para outro.

Origina-se na antigüidade, contudo, só teve um grande crescimento após a Revolução Industrial, quando começa a ser tratado como uma atividade sócio-econômica e deixa de ser apenas considerado como uma atividade de viagem.

No atual cenário mundial, o turismo é considerado uma atividade econômica de grande importância que possui como principais agentes econômicos, os consumidores com intuito de maximizar sua satisfação e os empresários, com o objetivo de aumentarem seus lucros, podendo gerar divisas, criar empregos, distribuir renda e aumentar a qualidade de vida da população local.

Segundo a EMBRATUR (1994) ${ }^{1}$ a atividade turística apresenta elevados índices de crescimento no contexto econômico internacional, sendo um dos maiores contribuintes do Produto Interno Bruto Mundial, movimentando aproximadamente US\$ 3,5 trilhões anualmente, expandindo sua atividade em 57\% no período de 1984 a 1994.

A Organização Mundial do Turismo - OMT estima o crescimento do turismo em 4,3\% nas próximas duas décadas (TIES, 2000).

Observa-se, portanto, que nos últimos anos, o turismo vêm se impondo como um setor que possui alto índice de crescimento, movimentando uma quantia elevada de dinheiro, ficando acima de setores como informática, indústria aeroespacial, indústria automobilística e diversos outros setores da economia (BARROS II, 1996).

1 EMBRATUR. Diretrizes da Política Nacional de Ecoturismo. Grupo de Trabalho Interministerial, organizado pelo Ministério do Meio Ambiente e da Amazônia Legal e pelo Ministério da Indústria, do Comércio e do Turismo, 1994. 
Contudo, o turismo necessita ser desenvolvido de forma planejada e consciente para que possa se tornar uma atividade sustentável e não predatória.

Dentro desse contexto, observa-se que o mercado turístico pode ser segmentado pelos tipos de atividades que determinam a motivação inicial do turista, como ecoturismo, turismo rural, turismo de aventura, turismo místico, turismo religioso, turismo históricocultural, turismo de negócios, turismo de eventos, turismo esportivo, turismo industrial, turismo de saúde, turismo social e turismo de incentivo. Muitas vezes, esses segmentos encontram-se interagindo para uma mesma motivação.

\section{2 - ECOTURISMO}

Uma grande diversidade de autores buscou conceituar e identificar as principais características e princípios do termo ecoturismo, existindo pouca divergência de idéias.

Em 1965, Hetzer ${ }^{2}$ identifica quatro princípios para o desenvolvimento de um turismo de forma responsável que são: respeitar as culturas locais, minimizar impactos ambientais, maximizar a satisfação do visitante e maximizar os benefícios para comunidades locais.

Em meados de 1980, vários países já haviam identificado o ecoturismo como uma ferramenta que possibilita o desenvolvimento associado à conservação.

Em 1987 é apresentada por Hector Ceballos-Lascuráin a primeira definição formal de ecoturismo:

“aquella modalidad del turismo que consiste en viajar a áreas naturales relativamente sin pertubar com el objeto específico de admirar, disfrutar y estudiar su paisaje, su flora y su fauna silvestre, así como las manifestaciones culturales (tanto presentes como passadas) que allí puedan encontrarse. En estos términos, el Ecoturismo implica un enfoque científico, estético o filosófico, sin que ello signifique que el ecoturista deba ser un científico, un artista o un filósofo profesional. Lo relevante aquí es que la persona que practica el Ecoturismo tiene la oportunidad de estar inmersa en la naturaleza de manera muy distinta a la que usualmente se presenta en la vida urbana cotidiana.

\footnotetext{
${ }^{2}$ HETZER, N. D. Environment, tourism, culture. LINKS, 1965. reeditado em Ecosphere,1970.
} 
Dicha persona a la larga adquirirá una conciencia y un conocimiento del medio ambiente natural (y, por extensión, del cultural), convirtiéndose así en alguien genuinamente involucrado en los temas conservacionistas” 3

No Brasil, em 1994, foi formado um grupo interministerial para formular uma Política Nacional de Ecoturismo, onde foi definido o conceito nacional de Ecoturismo como:

\begin{abstract}
"O ecoturismo é um segmento da atividade turística que utiliza, de forma sustentável, o patrimônio natural e cultural, incentiva sua conservação e busca a formação de uma consciência ambientalista através da interpretação do ambiente, promovendo o bemestar das populações envolvidas. " 4
\end{abstract}

Segundo ALBERNAZ (2003) $)^{5}$, essa definição possui quatro fundamentos importantes que devem nortear o desenvolvimento do Ecoturismo, sendo eles os seguintes:

- Conservação: o manejo e o uso sustentável dos recursos naturais são de extrema importância para conservação do meio ambiente. Devendo, portanto, a atividade turística primar pelo manejo e gestão do turismo de forma a assegurar a sustentabilidade dos ambientes visitados;

- Desenvolvimento Sustentável: deve propiciar uma melhora na qualidade de vida humana dentro dos limites da capacidade de suporte dos ecossistemas do nosso planeta (SOUZA, 2002). Portanto, para que o ecoturismo possa ser desenvolvido de maneira sustentável deve ser planejado e gerido de forma a minimizar ao máximo os danos ao ambiente, sendo, ao mesmo tempo, economicamente viável e socialmente eqüitativo, buscando atender as necessidades do presente sem comprometer as necessidades das gerações futuras;

\footnotetext{
${ }^{3}$ CEBALLOS-LASCURÁIN em entrevista a RON MADER, 2000 apud ALBERNAZ 2003.

${ }^{4}$ BARROS, Sílvio Magalhães e LA PENHA, Denise Hamu M. de, coord. Ecoturismo: Diretrizes para uma Política Nacional de Ecoturismo, "Conceituação", p. 19, Brasília, EMBRATUR, 1994.

${ }^{5}$ ALBERNAZ. Patrícia Cunha. O Ecoturismo como Instrumento de Conservação Ambiental e Viabilidade Econômica para RPPNs: Um Estudo de Caso no SVS Vagafogo. 2003.
} 
- A valorização da comunidade local: a atividade turística deve propiciar às comunidades locais benefícios e oportunidades de desenvolvimento, respeitando e valorizando seus traços culturais;

- A promoção de consciência ambiental: a conscientização ambiental está associada à interpretação ambiental, que é capaz de aliar os interesses do turismo com os interesses da conservação, ao mesmo tempo em que desenvolve uma consciência sobre o meio ambiente, reforçando atitudes, valores e medidas que favoreçam o desenvolvimento sustentável.

No mundo contemporâneo, o interesse pelo ecoturismo tem avançado na perspectiva de desenvolvimento socio-econômico e cultural, bem como na criação de mecanismos que garantam a utilização e preservação adequada do meio ambiente.

Segundo uma pesquisa realizada pela Organização Mundial do Turismo - OMT (2002), enquanto o turismo cresce $7 \%$ ao ano, o segmento de ecoturismo cresce mais de 20\%, apresentando comparativamente um elevado índice de crescimento. ${ }^{6}$

O rápido crescimento do ecoturismo proporcionou impactos sobre os recursos naturais de interesse turístico devido à ausência do planejamento da atividade junto a esses recursos levando a degradação ambiental, ao acúmulo de lixo, a poluição e a instabilidade e dependência econômica gerada pelo fato dos empregos e da renda estarem vinculados exclusivamente à atividade turística.

O Brasil possui um potencial promissor para o desenvolvimento do ecoturismo, diante da riqueza de sua diversidade ambiental, do seu patrimônio natural e de suas peculiaridades culturais.

“O ecoturismo praticado no Brasil, é uma atividade ainda desordenada, impulsionada, quase que exclusivamente pela oportunidade mercadológica, deixando a rigor de gerar os benefícios socioeconômicos e ambientais esperados e comprometendo,

\footnotetext{
${ }^{6}$ Estimativas da Organização Mundial do Turismo - OMT apud ANDREAZZI, Suely. Artigo: Ecoturismo Vira Mania Mundia. Jornal O Estado de São Paulo. 22 de outubro de 2003.
} 
não raro, o conceito e a imagem do produto ecoturístico brasileiros nos mercados interno e externo". 7

Para que o ecoturismo possa efetivamente constituir uma estrutura sólida, acessível e permanente, é preciso que esteja alicerçado de forma a acomodar adequadamente as peculiaridades de cada ecossistema e de cada traço da cultura popular brasileira. ${ }^{8}$

\section{3 - EDUCAÇÃO AMBIENTAL E PROCESSOS EDUCATIVOS}

No Brasil contemporâneo, há a crescente preocupação com a preservação da humanidade e a garantia do equilíbrio entre o homem e o meio ambiente.

Nesse sentido, tem-se constatado investimento no processo educativo transformador, estimulando a formação de sociedades socialmente justas e ecologicamente equilibradas, que conservam entre si relação de interdependência e diversidade.

Somos plenamente conscientes que não existe um verdadeiro processo educativo que não seja ativo e mutável. Portanto, a educação é um processo dinâmico, em permanente construção, que deve propiciar a reflexão, o debate e a possível mudança de paradigmas.

No Brasil, advindo da preocupação com a educação ambiental, foi promulgada a Lei 9.795/99, na qual são destacados os artigos $1^{\circ}$ e $2^{\circ}$ :

\footnotetext{
"Artigo $1^{\circ}$ - Entende-se por educação ambiental os processos por meios dos quais o indivíduo e a coletividade constroem valores sociais, conhecimentos, habilidades, atitudes e competências voltadas para a conservação do meio ambiente, bem de uso comum do povo, essencial à sadia qualidade de vida e a sua sustentabilidade.

Artigo $2^{\circ}$ - A educação ambiental é um componente essencial e permanente da educação nacional, devendo estar presente de forma articulada, em todos os níveis e modalidades do processo educativo, em caráter formal e não-formal.”9
}

\footnotetext{
${ }^{7}$ (EMBRATUR, 1994:9 apud Trigo,1999:49)

8 Transcrição de trecho do documento elaborado em 1994, por um Grupo de Trabalho Interministerial, organizado pelo MINISTÉRIO DO MEIO AMBIENTE E DA AMAZÔNIA LEGAL e pelo MINISTÉRIO DA INDÚSTRIA, DO COMÉRCIO E DO TURISMO, através da EMBRATUR.

${ }^{9}$ Diário Oficial da União - DOU de 28/04/99;Seção 1; pg 01
} 
Estes princípios educativos visam tornar efetiva a relação entre os meios educacionais e a vida, na perspectiva de novas e melhores formas de sociedade, tornandose eixos básicos de uma educação para a cidadania.

O ecoturismo é um instrumento capaz de contribuir para o desenvolvimento da educação ambiental, permitindo a interação entre o homem e a natureza, construindo, assim, uma consciência planetária de preservação da humanidade.

O ecoturismo e a educação ambiental caminham juntos, considerando que devem gerar mudanças na qualidade de vida e maior consciência de conduta pessoal, assim como harmonia dos seres humanos e destes com outras formas de vida.

\section{4-DESENVOLVIMENTO SUSTENTÁVEL}

O desenvolvimento sustentável tem sido considerado o alicerce para garantir à geração presente e futura, uma sociedade mais equilibrada e capaz de assegurar a qualidade e preservação da vida em todo o planeta.

O desenvolvimento sustentável surge no início dos anos 90, quando foi detectado que o crescimento econômico deveria ser mais justo a nível social e mais compatível com a preservação da base de recursos naturais. Houve, portanto, a intenção de introduzir um novo paradigma que possui estratégias mundiais para a conservação da natureza, levando o cidadão a pensar e agir, preparando o mundo frente os desafios dos próximos séculos, criando uma conscientização ambiental e humana.

Segundo a Comissão Mundial de Meio Ambiente e Desenvolvimento - CMMAD das Nações Unidas (1991), desenvolvimento sustentável é suprir as necessidades da população mundial atual sem comprometer as necessidades das gerações futuras. ${ }^{10}$

A ética mundial para o desenvolvimento sustentável incorpora os seguintes princípios: $^{11}$

\footnotetext{
${ }^{10}$ Segundo o relatório Nosso Futuro Comum publicado em 1991pela Comissão Mundial de Meio Ambiente e Desenvolvimento (CMMAD)

${ }^{11}$ IUCN, UNEP e WWF. Caring for the Earth: a Stratey for Sustainable Living. 1991 apud adaptação disponível na internet em: <http://planeta.terra.com.br/lazer/staruck/sustentavel.htm>, acesso em 25 de mar. de 2005
} 
- Os seres humanos fazem parte da comunidade da vida;

- Todos os seres humanos têm os mesmos direitos fundamentais;

- Todas as sociedades são responsáveis pelo respeito e proteção dos direitos dos outros;

- Todas as formas de vida merecem respeito independentemente do seu valor para as pessoas;

- Todas as pessoas devem utilizar os recursos de um modo equilibrado;

- Os benefícios e custos do uso dos recursos devem ser justamente partilhados por todos;

- a proteção dos direitos mundial transcende todas barreiras culturais, ideológicas e geográficas.

No documento Ciência \& Tecnologia para o Desenvolvimento Sustentável ${ }^{12}$ são consideradas as seguintes dimensões de sustentabilidade:

- Sustentabilidade social: ancorada no princípio da equidade na distribuição de renda e bens, no princípio da igualdade de direitos a dignidade humana e no princípio de solidariedade dos laços sociais;

- Sustentabilidade ecológica: ancorada no princípio da solidariedade com o planeta e suas riquezas e com a biosfera que o envolve;

- Sustentabilidade econômica: avaliada a partir da sustentabilidade social propiciada pela organização da vida material;

- Sustentabilidade espacial: norteada pelo alcance de uma equanimidade nas relações inter-regionais e na distribuição populacional entre o rural/urbano e o urbano;

- Sustentabilidade político-institucional: que representa um pré-requisito para a continuidade de qualquer curso de ação a longo prazo;

${ }^{12}$ Documento elaborado para o Ministério do Meio Ambiente - Consórcio CDS/UnB - Abipti - Ciência \& Tecnologia para o Desenvolvimento Sustentável. Brasília, 2000, pág.42 
- Sustentabilidade cultural: modulada pelo respeito à afirmação do local, do regional e do nacional, no contexto da padronização imposta pela globalização.

Como pode ser detectado, o desenvolvimento sustentável do turismo tem suas bases nos princípios e dimensões aqui tratados, mas no Brasil, foram estabelecidos pelo Conselho Brasileiro para o Turismo Sustentável - CBTS (2001) ${ }^{13}$ princípios específicos para o turismo, quais sejam:

- Respeitar a legislação vigente: o turismo deve respeitar a legislação vigente, em todos os níveis, no país e as convenções internacionais de que o país é signatário;

- Garantir os direitos das populações locais: o turismo deve buscar e promover mecanismos e ações de responsabilidade social, ambiental e de equidade econômica, inclusive a defesa dos direitos humanos e de uso da terra, mantendo ou ampliando, a médio e longo prazos, a dignidade dos trabalhadores e comunidades envolvidas;

- Conservar o ambiente natural e sua biodiversidade: em todas as fases de implantação e operação, o turismo deve adotar práticas de mínimo impacto sobre o ambiente natural, monitorando e mitigando efetivamente os impactos, de forma a contribuir para a manutenção das dinâmicas e processos naturais em seus aspectos paisagísticos, físicos e biológicos, considerando o contexto social e econômico existente;

- Considerar o patrimônio cultural e valores locais: o turismo deve reconhecer e respeitar o patrimônio histórico-cultural das localidades receptoras e ser planejado, implementado e gerenciado em harmonia às tradições e valores culturais, colaborando para seu desenvolvimento;

- Estimular o desenvolvimento social e econômico dos destinos turísticos: o turismo deve contribuir para o fortalecimento das economias locais, a qualificação das

${ }^{13}$ Conselho Brasileiro para o Turismo Sustentável - CBTS. Princípios do Turismo Sustentável no Brasil. Versão 4.2 de outubro de 2001. Disponível na Internet em: <http://www.wwf.org.br/projetos/siteturismo_cbtsprincipios.htm>, acesso em: 25 de março de 2005. 
pessoas, a geração crescente de trabalho, emprego e renda e o fomento da capacidade local de desenvolver empreendimentos turísticos;

- Garantir a qualidade dos produtos, processos e atitudes: o turismo deve avaliar a satisfação do turista e verificar a adoção de padrões de higiene, segurança, informação, educação ambiental e atendimento estabelecidos, documentados, divulgados e reconhecidos;

- Estabelecer o planejamento e a gestão responsáveis: o turismo deve estabelecer procedimentos éticos de negócios visando engajar a responsabilidade social, econômica e ambiental de todos os integrantes da atividade, incrementando o comprometimento do seu pessoal, fornecedores e turistas, em assuntos de sustentabilidade desde a elaboração de sua missão, objetivos, estratégias, metas, planos e processos de gestão.

\section{5 - PLANEJAMENTO}

A definição de planejamento pode ser dada a partir de três perguntas:

- O que se quer alcançar? (o sonho);

- A que distância se está do que se quer alcançar? (diagnóstico);

- O que será feito para diminuir a distância? (programação);

O planejamento, segundo Ignarra (s.d.), é um processo lógico de pensamento mediante o qual o ser humano analisa a realidade que o cerca e estabelece meios que lhe permitirão transformá-la de acordo com seus interesses e aspirações.

O planejamento como processo lógico de pensamento realiza as seguintes operações:

- Reflexão: é o diagnóstico, a fase de estudo, do conhecimento, à análise e o estudo das alternativas; 
- Equacionamento: corresponde ao conjunto de informações significativas para a tomada de decisões, encaminhados pelos técnicos de planejamento aos centros decisórios. A função essencial do planejamento, como instrumento técnico, é aumentar a capacidade e melhorar a qualidade do processo de adoção de decisões, ao oferecer dados básicos da situação e dados das tendências e projeções futuras;

- Decisão: ocorre no momento de definição dos objetivos e das metas, de escolha de prioridades e de alternativas de intervenção, de modificação nos níveis e na composição dos recursos, de distribuições de responsabilidades;

- Operacionalização: relaciona-se com o detalhamento das atividades necessárias à efetivação das decisões tomadas, cabendo aos técnicos sua consubstanciação em planos, programas e projetos, e, na ocasião oportuna, as medidas para sua implementação.

- Ação: refere-se às providências que transformarão em realidade o que foi planejado;

- Revisão: corresponde ao acompanhamento da implementação, o controle e a avaliação que realimentarão o ciclo de planejamento.

Como o planejamento decorre do fato de um contínuo processo de tomadas de decisões, se caracteriza por envolver uma função política. Nesse processo, segundo Lozano e Ferrer, ${ }^{14}$ não é fácil se estabelecer uma inter-relação entre o elemento técnico (de concepção) e o elemento político (de decisão). Para que se estabeleça essa inter-relação é necessário que ocorra:

- A definição clara das funções e a articulação funcional e operativa entre órgãos técnicos e centros decisórios;

- Uma “atitude favorável” do poder decisório em relação às mudanças propostas;

\footnotetext{
${ }^{14}$ Lozano e Ferrer. El Planeamiento de la Educación.Chile.1978
} 
- Que o planejamento, como técnica, se faça respeitável por sua eficácia, oportunidade e apresentação.

\section{2 - METODOLOGIA}

O presente trabalho foi elaborado com base em estudos bibliográficos, nas experiências já vivenciadas no atrativo Poço Azul, em visitas específicas de observação direta ao local e na aplicação de 35 questionários a visitantes do atrativo.

Para elaboração dos questionários aplicados (Anexo A), foram levados em conta a necessidade de identificar as características sócio-econômicas dos visitantes, seus anseios e sua visão sobre o local utilizado.

\section{3- FAZENDA POÇO AZUL}

\section{1- CARACTERIZAÇÃO}

\subsection{1- Localização}

A Fazenda Poço Azul é uma propriedade privada rural que está localizada na Região Administrativa de Brazlândia - Distrito Federal, na longitude $48^{\circ} 03^{\prime} 16^{\prime \prime}$ W - latitude $15^{\circ}$ 36’ 03’' S, em uma altitude de 1.220 metros acima do nível do mar.

\subsection{2- Acesso:}

O acesso a Fazenda Poço Azul, se dá saindo da rodoviária do Plano Piloto pela saída norte sentido Planaltina - DF, passando pelo Posto Colorado fazendo o retorno sentido Brazlândia pela DF 001, seguindo até a entrada da Fazenda Poço Azul.

A estrada de acesso a Fazenda Poço Azul pela saída norte, possui $38 \mathrm{Km}$ de asfalto e $7 \mathrm{Km}$ de estrada de terra até a entrada do atrativo. O acesso pode se dar, também, pela saída oeste, saindo da rodoviária pelo eixo monumental norte entrando na DF 095 
(estrutural), entrando a direita no balão localizado na entrada de Taguatinga, tomando a DF 001, seguindo até a entrada da Fazenda Poço Azul.

Um mapa que melhor permite a visualização do acesso encontra-se disponível no Anexo B.

\subsection{3- Distância da Capital:}

A Fazenda Poço Azul se localiza a uma distância de aproximadamente 45 Km da rodoviária do Plano Piloto - Brasília (DF).

\subsection{4- Atrativos Naturais:}

Sua região é cortada pelo Córrego Poço Azul afluente do Rio da Palma do qual originam-se um complexo de aproximadamente cinco cachoeiras (com mais de 3 metros de altura), corredeiras e algumas quedas menores.

Possui uma área com vegetação de cerrado que varia entre matas de galeria, campos e matas ciliares, abrigando uma fauna diversificada onde podem ser encontrados animais como carcará, andorinhas, diversos tipos de cobras, lagartos, macacos e aves nativas, além de paisagens encantadoras que podem ser vistas de mirantes naturais.

O conjunto desses recursos naturais faz com que a Fazenda Poço Azul seja capaz de atrair visitantes, principalmente regionais, podendo ser considerada como um atrativo natural do Distrito Federal.

A Fazenda Poço Azul possui atrativos para pessoas de vários perfis: para os que gostam de praticar esportes radicais com trilhas íngremes, lugares para mergulho e paredões para a prática de rapel; para os mais moderados, existe uma paisagem de linda beleza a ser contemplada, além de poderem usufruir das águas azuis disponíveis no atrativo. Mas, observa-se que o local não tem total acessibilidade, dificultando o acesso de pessoas portadoras de deficiência e/ou com mobilidade reduzida, como o caso de pessoas idosas, gestantes, obesos e outros. 
Portanto, possui um enorme potencial turístico para que seja desenvolvido o segmento de ecoturismo de forma sustentável.

\subsection{5- Taxa de Visitação:}

A Fazenda Poço Azul está aberta a visitação mediante o pagamento de uma taxa de $\mathrm{R} \$ 15,00$ (quinze reais) por carro.

\subsection{6- Capacidade de Carga}

A Fazenda Poço Azul não possui uma capacidade de carga definida, o que leva muitas vezes a uma superlotação de alguns atrativos e consequentemente a um maior impacto sobre o meio natural.

\subsection{7- Normas de Visitação}

A Fazenda não possui normas de visitação, o que permite aos visitantes praticarem atividades predatórias ou irresponsáveis como:

- A realização de churrascos nas margens dos rios, sobre churrasqueiras de pedras improvisadas, gerando lixo e restos de alimentos que normalmente são deixados no local podendo prejudicar o ecossistema local, além das brasas restantes que em períodos de seca, podem causar grandes incêndios;

- A ingestão de bebidas alcóolicas e a utilização de drogas por visitantes que costumam saltar das cachoeiras sem antes verificar a profundidade e a inexistência de pedras e tronco de árvores no fundo do rio, pode ocasionar diversos tipos de acidentes;

- A inscrição de nomes e datas em pedras e árvores localizadas nas margens do rio. 


\subsection{8- Sinalização}

- Sinalização interna: existe apenas uma placa indicativa localizada logo após a entrada do empreendimento, apontando o caminho para as duas cachoeiras mais visitadas.

- Sinalização externa: na estrada DF 001 sentido Sobradinho / Brazlândia, existem três placas que indicam a distância da Fazenda Poço Azul e duas placas localizadas na entrada que dá acesso à Fazenda.

\subsection{9- Sistema de Limpeza}

- Na Fazenda Poço Azul não existem lixeiras espalhadas pelas trilhas ou atrativos.

- Existe um incentivo para o visitante recolher seu lixo, onde a administração da Fazenda entrega o saco de lixo na entrada e devolve o valor de $\mathrm{R} \$ 5,00$ (cinco reais) na saída para os que devolvem o lixo. Pela grande quantidade de lixo encontrada nas cachoeiras e trilhas como latas de cerveja e refrigerante, copos e pratos descartáveis, papéis, garrafas de vidro, chinelos e outros, observou-se que o incentivo não é suficiente para que o visitante recolha o lixo.

- O administrador da Fazenda percorre a trilha e as cachoeiras toda segunda feira, recolhendo o lixo ali encontrado.

\subsubsection{0- Serviço de Condução de Visitantes}

Na Fazenda Poço Azul não existem guias de turismo especializados ou capacitados para acompanhar, orientar e prestar informações aos visitantes sobre a ecologia e os recursos naturais do local e para fiscalizar o uso do atrativo, havendo somente orientações por parte da pessoa que está na entrada da Fazenda; 


\subsubsection{1- Educação Ambiental}

A Fazenda não desenvolve nenhum trabalho de educação ambiental e nem presta informações sobre a ecologia ou recursos naturais existentes deixando de contribuir para uma sensibilização ambiental dos visitantes.

\subsubsection{2- Trilhas}

O acesso às principais cachoeiras (Cachoeira da Gruta / Corredeiras) se dá por duas trilhas que possuem grande largura e permitem a passagem de carro até próximo às cachoeiras. Principalmente a estrada de terra que dá acesso à Cachoeira da Gruta, que está localizada em uma descida de morro e se estende até próximo às margens do rio, provoca, no período de chuva, a descida de correntes de água que levam a erosão do solo e conseqüentemente o seu assoreamento.

Existem, também, diversas trilhas de pequena largura que se encontram espalhadas pela propriedade, porém, não possuem sinalização adequada que seja capaz de orientar os visitantes em relação aos atrativos, levando muitas pessoas a permanecerem apenas no atrativo mais próximo da estrada sem tomar conhecimento da existência dos demais.

\subsubsection{3- Equipamentos}

- Equipamentos de higiene: os banheiros existentes são pequenos, sujos, precários e se encontram em péssimas condições de uso, o que leva os visitantes a realizarem suas necessidades fisiológicas próximo às trilhas ou atrativos gerando odores e aspectos visuais não agradáveis;

- Equipamentos de saúde: Não existem equipamentos e nem pessoas capacitadas para prestarem socorro caso haja algum acidente no local; 


\subsubsection{4- Alimentos e Bebidas}

Não existe restaurante ou lanchonete dentro da Fazenda Poço Azul. A aproximadamente 500 metros da entrada da Fazenda se encontra funcionando um bar que comercializa bebidas e que futuramente, segundo seu proprietário, servirá almoço.

\subsubsection{5- Segurança}

A Fazenda Poço Azul não possui um sistema de segurança que acompanhe o desenvolvimento das atividades dos visitantes e que possa garantir o bom uso dos atrativos naturais e uma correta conduta dos usuários.

As trilhas possuem alguns trechos íngremes ou com alto índice de dificuldade que não oferecem pontos de apoio para se manter o equilíbrio, podendo ocasionar acidentes.

\subsubsection{6- Marketing}

A Fazenda Poço Azul não possui estratégia e nem plano de Marketing, contudo por se tratar de um atrativo turístico da região, encontra-se divulgada em alguns sites, jornais, revistas e guias turísticos de Brasília, sem ter investimentos do proprietário nessa divulgação.

\subsubsection{7- Administração}

A Fazenda Poço Azul é administrada, há alguns anos, pelo Sr. Nonato Raimundo que ali reside com sua família.

Observou-se em entrevista realizada no dia 06 de março de 2005, que sua concepção no que se refere ao desenvolvimento de atividades de ecoturismo é leiga, havendo insuficiente conhecimento sobre o assunto, principalmente sobre sustentabilidade. É uma pessoa humilde, acessível e que se encontra aberta para propostas de parceria. 
Quanto à melhoria da infra-estrutura, segundo o administrador, um dos grandes problemas encontrados é o vandalismo por parte dos visitantes, pois já houve a implementação de banheiros e placas de sinalização nas trilhas, porém, os banheiros foram depredados tendo suas portas arrancadas e suas louças quebradas e as placas das trilhas foram arrancadas e queimadas.

O administrador informou que a fazenda recebe em média entre 60 e 100 visitantes por dia nos final de semana, sendo considerado por ele um número baixo de visitantes.

Segundo o Sr. Nonato, o planejamento turístico da fazenda foi realizado pelo proprietário que é advogado.

Concorda que a forma como o turismo se desenvolve na Fazenda Poço Azul provoca impactos negativos sobre o meio natural e acredita que seria interessante implementar um centro de atendimento ao turista que pudesse explicar a história, a ecologia e as normas de visitação. Manifestou, também, que deveria existir guias de turismo para acompanhar, orientar e fiscalizar o respeito às normas de visitação pelos usuários.

Quanto às áreas ambientalmente degradadas, afirmou o administrador, que é possível ser proibida a visitação para realização de um processo de recuperação e futuramente utilizá-la de forma menos impactante.

\section{2- PESQUISA}

Ao elaborar o formulário (Anexo A) para a pesquisa, teve-se o cuidado de coletar dados que possibilitassem o levantamento do perfil dos usuários da Fazenda Poço Azul, bem como a opinião sobre o atrativo. Considerou-se importante, obter dados que permitam desenvolver um planejamento adequado para a estruturação da infra-estrutura e dinamização das atividades, contribuindo para o desenvolvimento do turismo sustentável e a expansão dos negócios do atrativo no mercado de Ecoturismo, crescente na região do Distrito Federal. 
Admite-se, que são levantamentos iniciais e que para aprofundar os estudos de campo, necessitaria de pesquisas mais especificas, sendo necessário uma elaboração mais detalhada e estruturada e aplicada em ocasiões diversas, permitindo um maior conhecimento do universo estudado. Mas, inicialmente é importante identificar as características sócio-culturais e econômicas dos visitantes, seus anseios e sua visão sobre os atrativos disponíveis.

Apesar da pesquisa ser aplicada em um só dia, 06 de março de 2005, onde foram entrevistados 35 visitantes da Fazenda Poço Azul, esse é um atrativo que é muito freqüentado pelo pesquisador, que vem analisando as estruturas disponibilizadas frente aos conhecimentos adquiridos na sua formação profissional.

Inicialmente, a aplicação da pesquisa estava programada para ser realizada em 4 (quatro) semanas, sendo duas visitas em finais de semana e duas durante a semana. Mas, devido o acumulo de chuvas nessa região, não foi possível seguir a programação e ao aparecer um dia ensolarado, foi-se imediatamente a campo para aplicação da referida pesquisa.

\subsection{1- Resultados da Pesquisa}

Os resultados dessa pesquisa são apresentados por gráficos, tendo-se comentários sobre o intento da pergunta e seus resultados dentro dos parâmetros de interesse para diagnosticar o perfil dos visitantes e sua visão sobre o atrativo.

Pergunta 01 - Qual o Local de Moradia? UF?

Intento: identificar a abrangência do público alvo - âmbito local, regional, nacional e internacional.

Resultado: detecta-se que 91,40\% dos entrevistados são oriundo do Distrito Federal e 8,60\% de Goiás, podendo ser considerado um atrativo de abrangência local/regional. 
Figura 01 - Local de Origem dos Visitantes

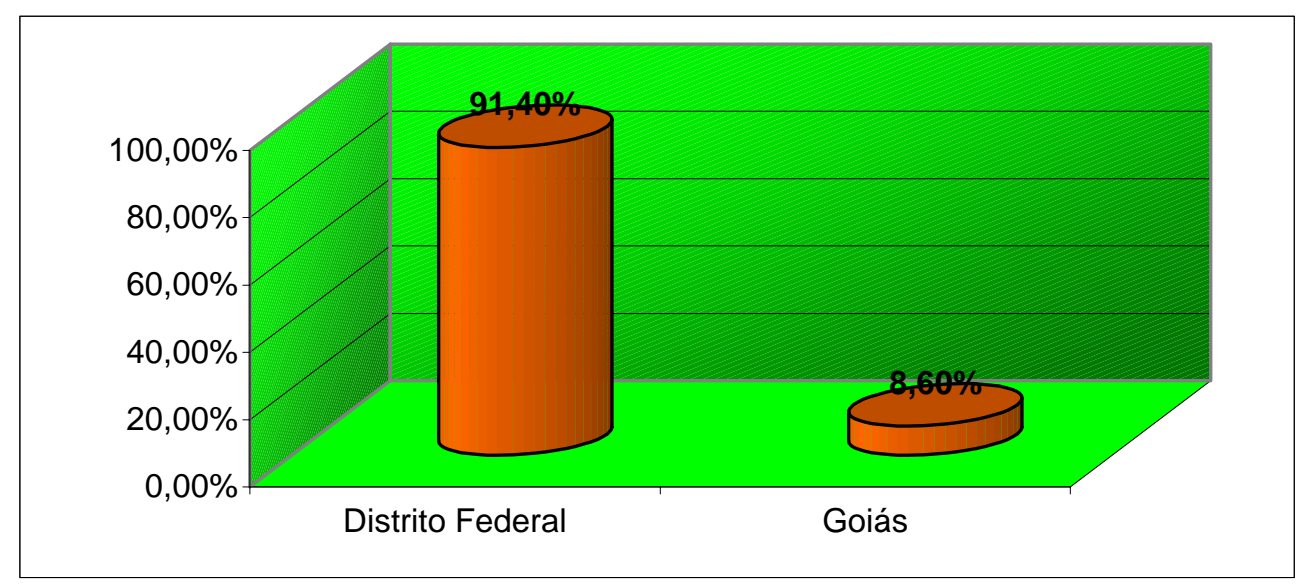

Figura 02 - Local de Origem dos Visitantes

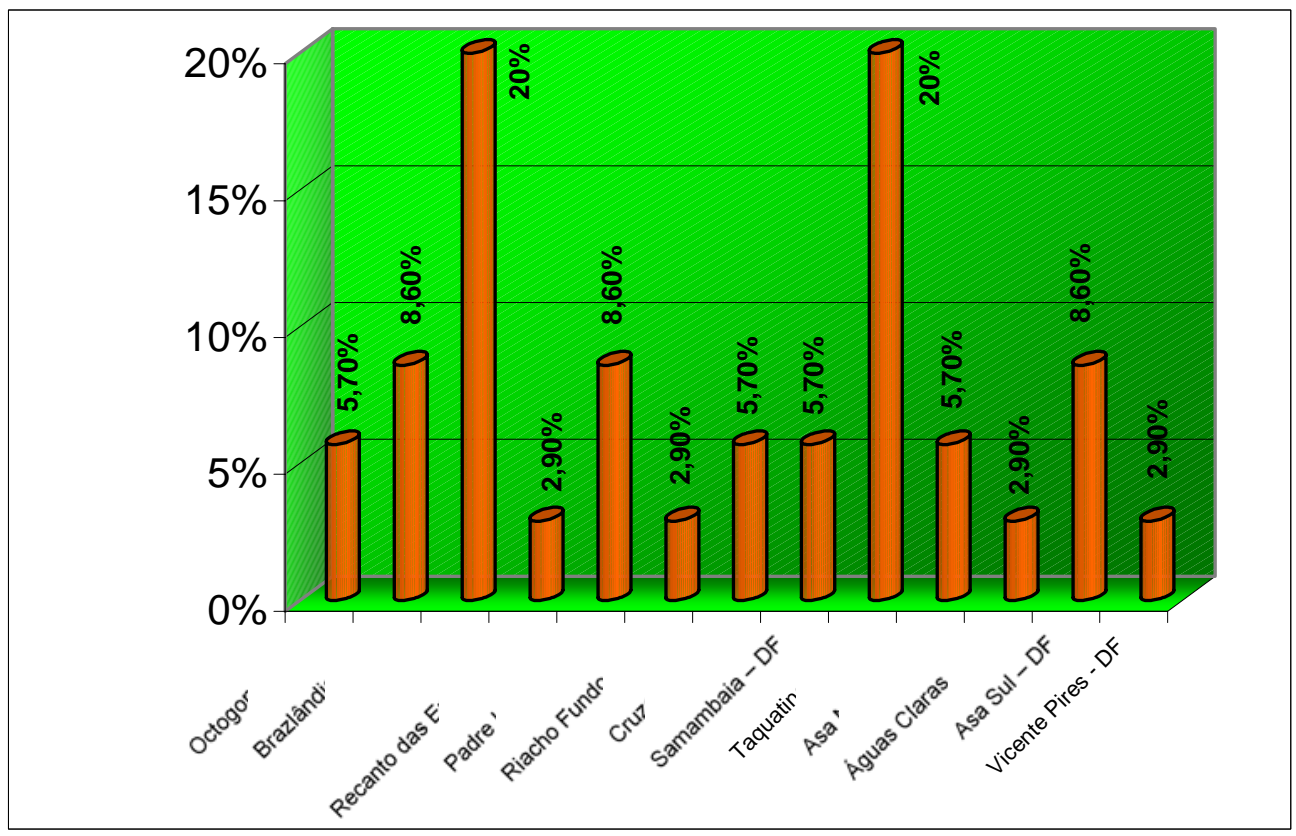

\section{Pergunta 02 - Qual Sua Idade?}

Intento: identificar a faixa etária dos visitantes buscando definir o público alvo preferencial contribuindo para a caracterização do perfil dos visitantes. 
Resultado: constata-se que 74,28\% do público visitante é formado por jovens entre 16 e 25 anos, podendo ser considerado o público preferencial.

Figura 03 - Faixa Etária dos Visitantes

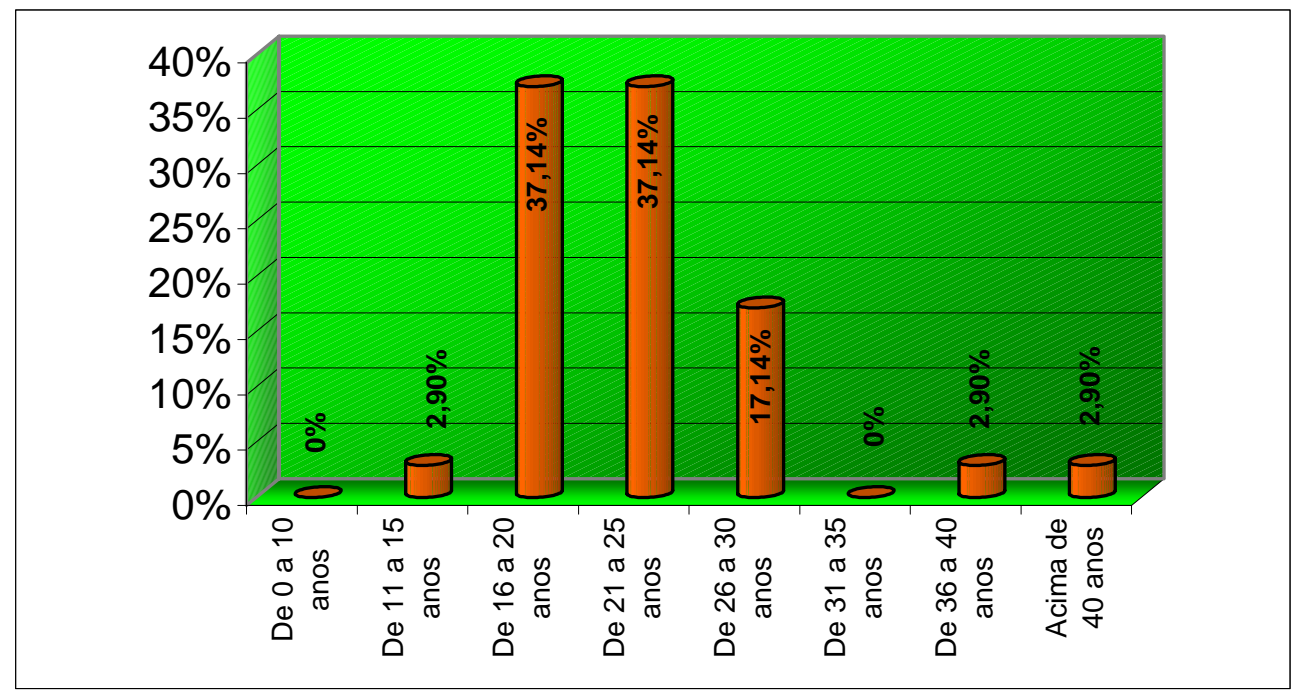

\section{Pergunta 03 - Escolaridade?}

Intento: identificar o grau de escolaridade permitindo visualizar o perfil sócio-cultural dos visitantes e contribuir para a identificação de nível de conhecimento e esclarecimento sobre preservação de meios naturais, além de permitir a adequação do planejamento de instrumentos de informações ao usuário do atrativo.

Resultado: detecta-se que 45,70\% possuem o $2^{\circ}$ grau completo e $31,40 \%$ o nível superior incompleto, o que se justifica pelo público alvo preferencial ser jovem. Na análise dos dados, encontrou-se somente 01 (uma) pessoa com o $1^{\circ}$ grau incompleto, 02 (duas) com o $1^{\circ}$ grau completo e 01 (uma) com o $2^{\circ}$ grau incompleto, observando que são pessoas com idade superior a 20 anos. Portanto, pode-se considerar o nível elevado de escolaridade dos visitantes. 
Figura 04 - Nível de Escolaridade dos Visitantes

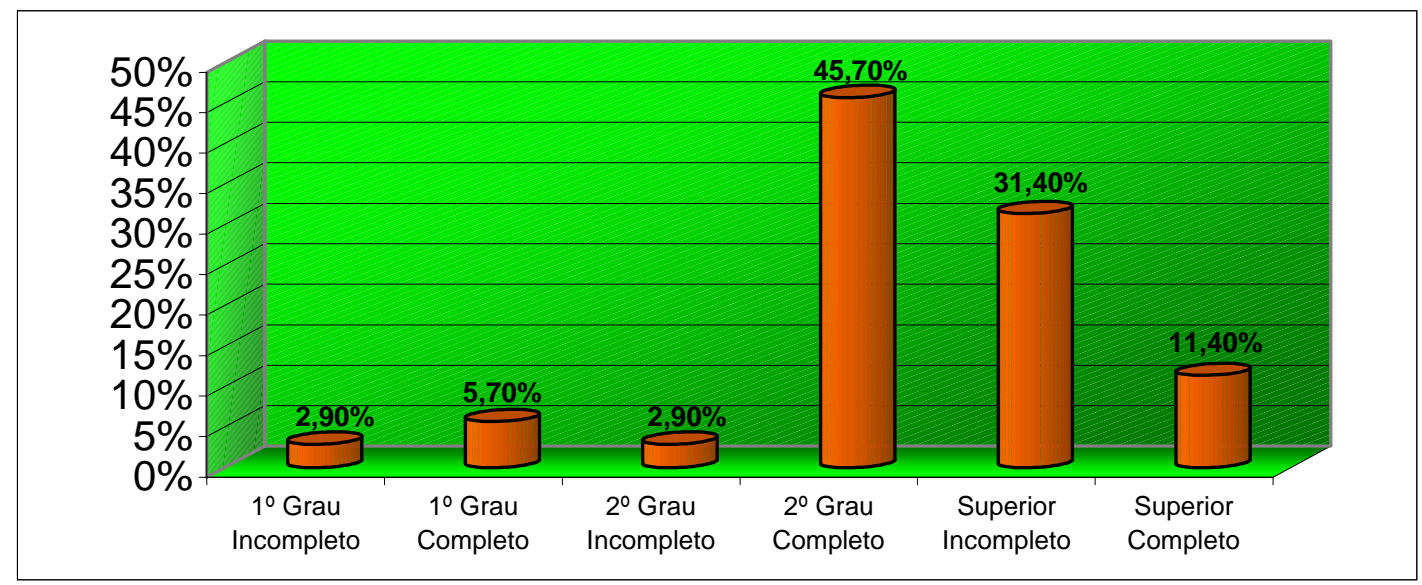

\section{Pergunta 04 - Profissão?}

Intento: identificar a profissão dos visitantes contribuindo para a definição do perfil sócioeconômico e identificação dos tipos de profissionais que se interessam pela natureza, caracterizando o perfil do usuário.

Resultado: detecta-se que 34,28\% são pessoas que somente estudam, 8,57\% de pessoas desempregadas e 57,15\% de profissionais diversificados, não sendo identificado algum tipo de profissão preferencial, observando-se que somente 04 (quatro) pessoas, ou seja, 11,42\% possuem profissão de nível superior.

Figura 05 - Profissão dos Visitantes

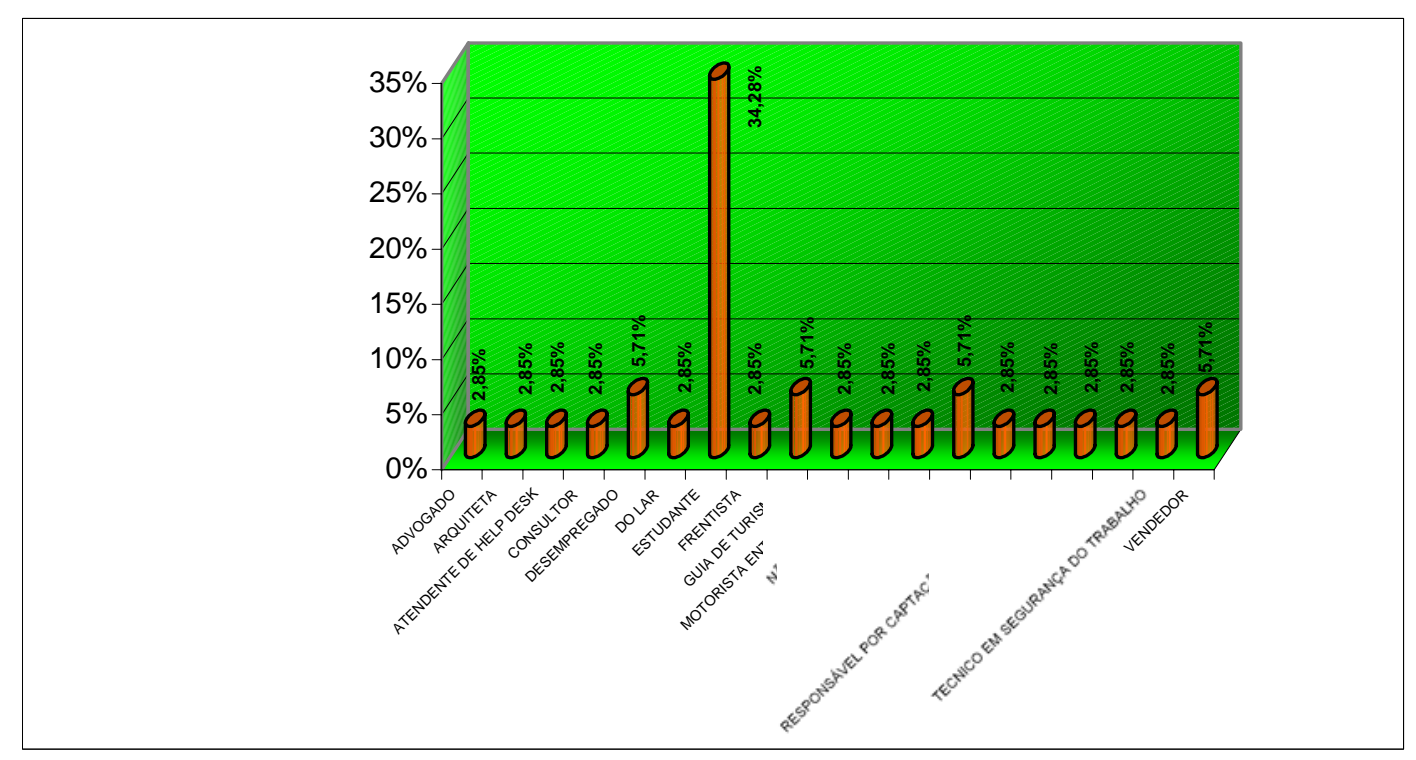




\section{Pergunta 05 - Renda Mensal?}

Intento: identificar a faixa de renda mensal dos visitantes contribuindo para visualizar o perfil sócio-econômico dos usuários do atrativo.

Resultado: constata-se que a quantidade de jovens e estudantes no atrativo contribui para que o nível de renda mensal dos visitantes seja baixo, tendo-se $29 \%$ de visitantes sem renda, 22\% de visitantes na faixa de renda entre 01 e 500 reais, e 29\% na faixa entre 501 e 1000 reais. Somente 04 (quatro) pessoas, ou seja, 12\% possuem renda maior que 2000 reais.

Figura 06 - Renda Mensal dos Visitantes

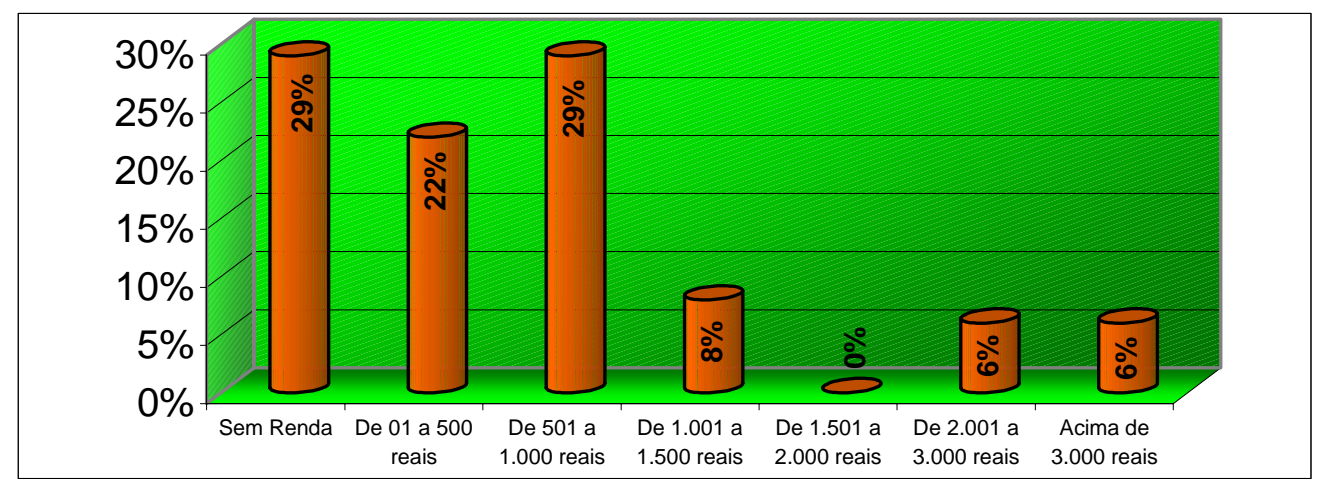

\section{Pergunta 06 - É a Primeira Vez que Visita o Poço Azul ou Já Visitou em Outra Ocasião?}

Intento: identificar o interesse do visitante, permitindo caracterizar se são novos ou se há uma freqüência de utilização do atrativo.

Resultado: detecta-se que 38\% das pessoas entrevistadas estavam pela primeira vez visitando o atrativo, $8 \%$ pela segunda vez, $20 \%$ entre a terceira e a quinta vez, $8 \%$ entre seis e dez vezes e $26 \%$ já voltaram mais de dez vezes. Portanto, 62\% dos entrevistados voltaram novamente ao atrativo, podendo-se considerar que um percentual dos 38\% dos usuários que visitavam pela primeira vez são potenciais para novas visitas. 
Figura 07 - Quantidade de Vezes que Visitou o Atrativo

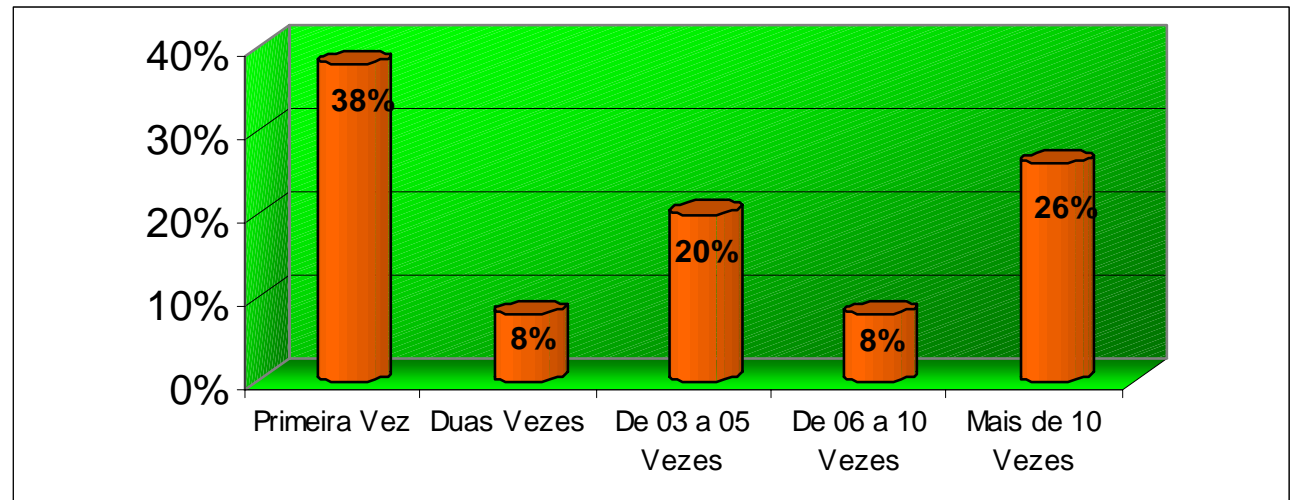

\section{Pergunta 07 - Costuma Vir Acompanhado de Quantas Pessoas?}

Intento: identificar a existência e tamanho dos grupos usuários do atrativo.

Resultado: detecta-se que nenhum visitante veio sozinho ou acompanhado de 01 (uma) pessoa, havendo 57\% dos entrevistados acompanhado de 02 (duas) a 05 (cinco) pessoas e 43\% acompanhado de mais de 05 (cinco) pessoas. Considerando-se um atrativo preferencial para grupos de tamanho pequeno.

Figura 08 - Os Visitantes Costumam Vir Acompanhados de Quantas Pessoas

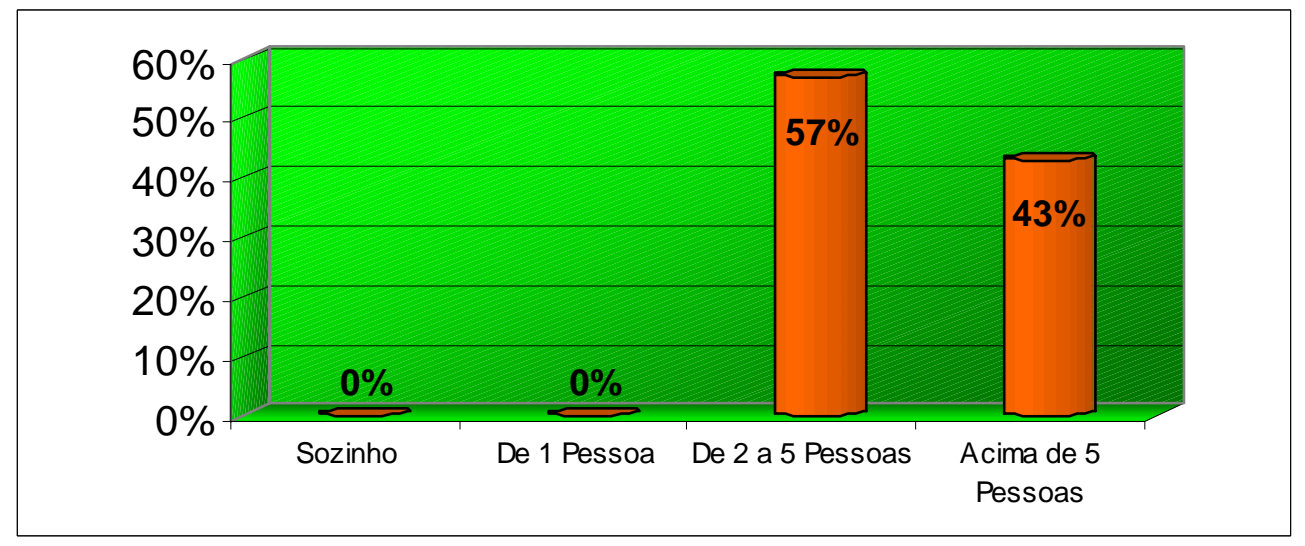

\section{Pergunta 08 - Veio Por Intermédio de Excursão ou Viagem Própria?}

Intento: identificar a inserção do atrativo no mercado de turismo. 
Resultado: verifica-se que $100 \%$ dos entrevistados se encontravam visitando o atrativo por intermédio de viagem própria e nenhum por intermédio de excursão. Portanto, detecta-se a ausência de excursões no atrativo e a inexistência de parcerias com agências de viagens e operadoras turísticas locais que busquem promover, organizar e ofertar excursões para a Fazenda Poço Azul.

Figura 09 - A Visita Ocorreu Por Intermédio de Excursão ou Viagem Própria

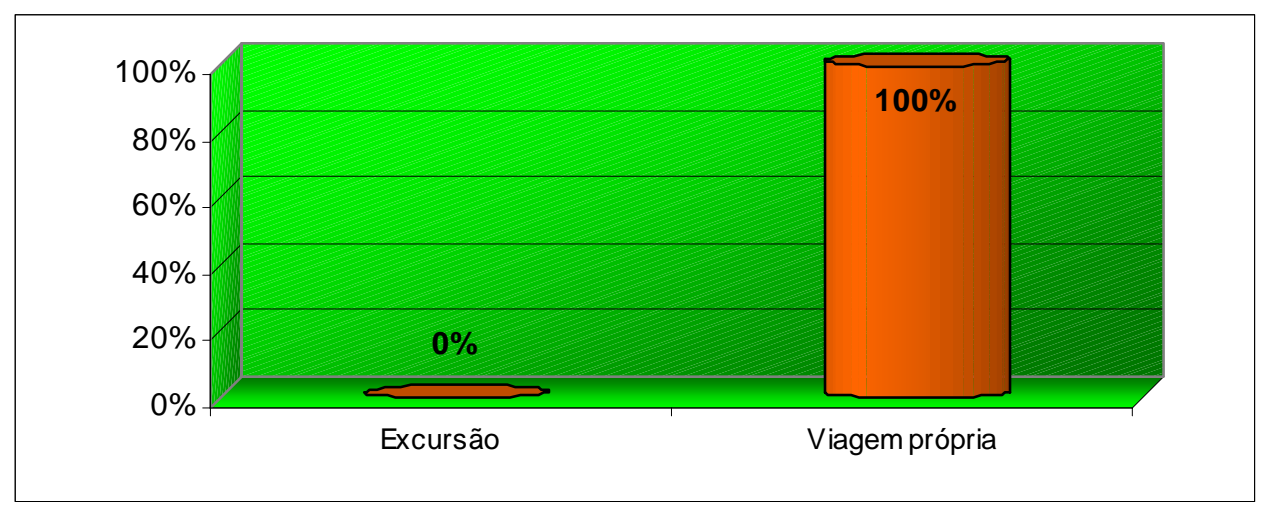

\section{Pergunta 09 - Qual o Meio de Transporte Utilizado?}

Intento: identificar os meios de transportes utilizado para elaboração do planejamento de infra-estrutura necessária para atender a demanda.

Resultado: verifica-se que $100 \%$ dos entrevistados se deslocam até o atrativo utilizando automóvel particular. Portanto, observa-se que existe uma predominância no meio transporte utilizado pelos visitantes para se deslocarem até o atrativo, podendo esse fato estar relacionado com a carência de meios de transporte público que passem próximo do atrativo e com a falta de excursões que se utilizem outros meios de transporte para sua realização.

Figura 10 - Meio de Transporte Utilizado Pelo Visitante

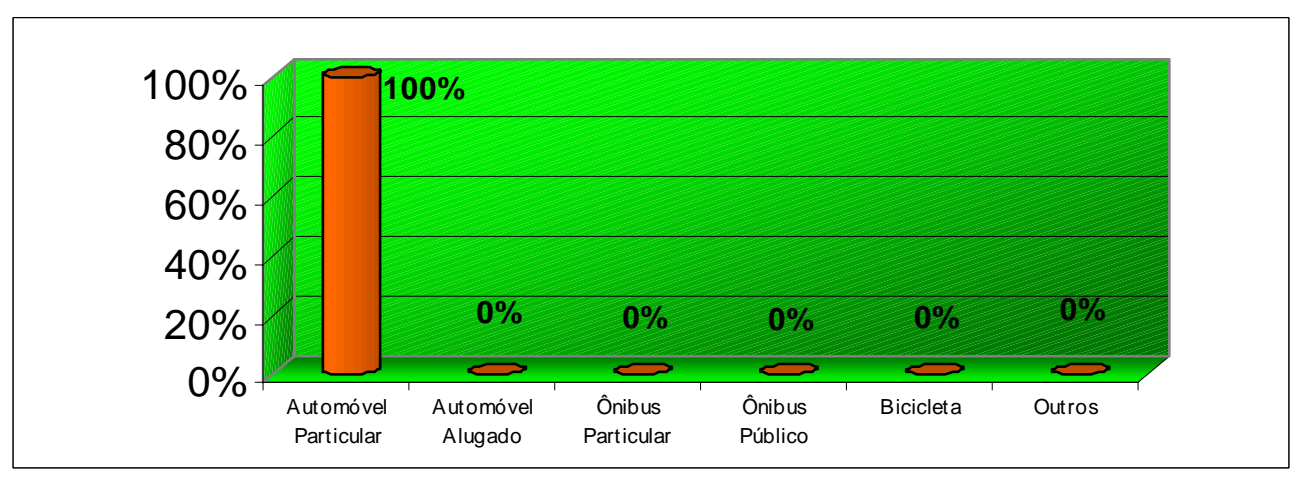




\section{Pergunta 10 - Como Ficou Sabendo do Poço Azul?}

Intento: identificar os meios de comunicação e de divulgação que disponibilizam informações sobre o atrativo.

Resultado: verifica-se que $100 \%$ dos entrevistados souberam do atrativo por intermédio de amigos ou parentes. Portanto, detecta-se que a principal forma de divulgação do atrativo acontece por intermédio de visitantes que transmitem informações sobre o atrativo para colegas e amigos, podendo esse fato estar relacionado com a inexistência de plano de marketing, com a falta de uma campanha de divulgação adequada.

Figura 11 - Maneira Pela Qual o Visitante Ficou Sabendo do Atrativo

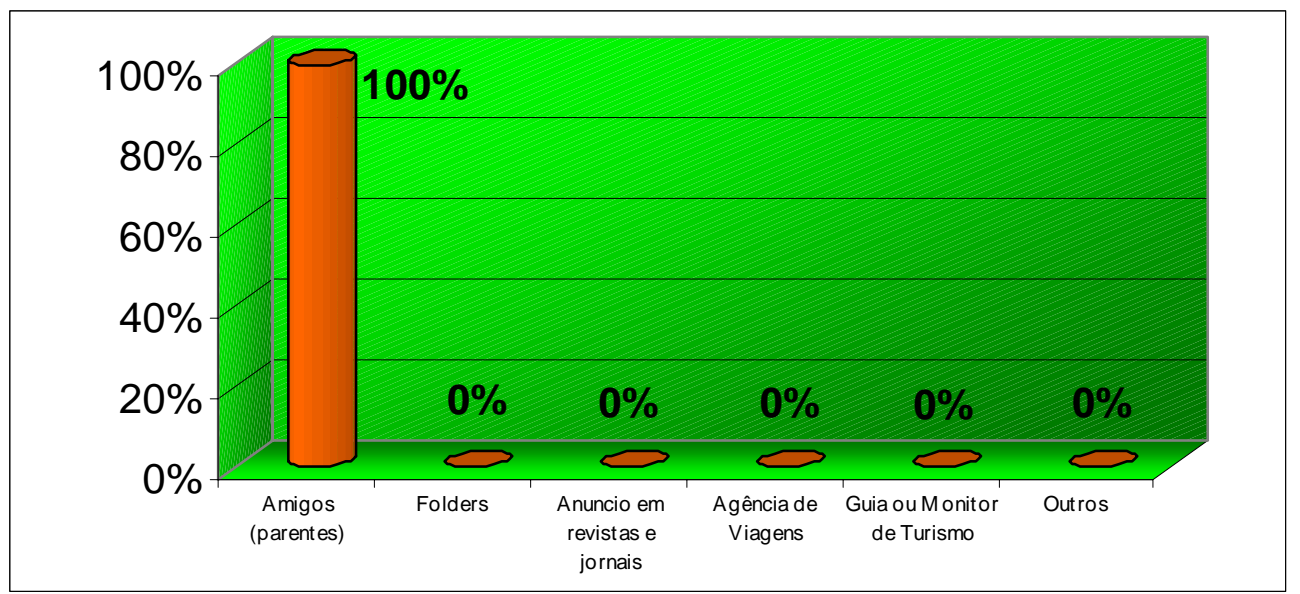

\section{Pergunta 11 - O Acesso ao Poço Azul Está em Boas Condições?}

Intento: conhecer a opinião do visitante quanto à infra-estrutura oferecida na Fazenda Poço Azul.

Resultado: verifica-se que 97\% dos entrevistados consideraram que o acesso ao atrativo encontra-se em péssimas condições, principalmente, no que diz respeito ao trecho da estrada que não está asfaltada, possuindo buracos e atoleiros. 
Figura 12 - O Visitante Considera que o Acesso ao Atrativo está em Boas Condições

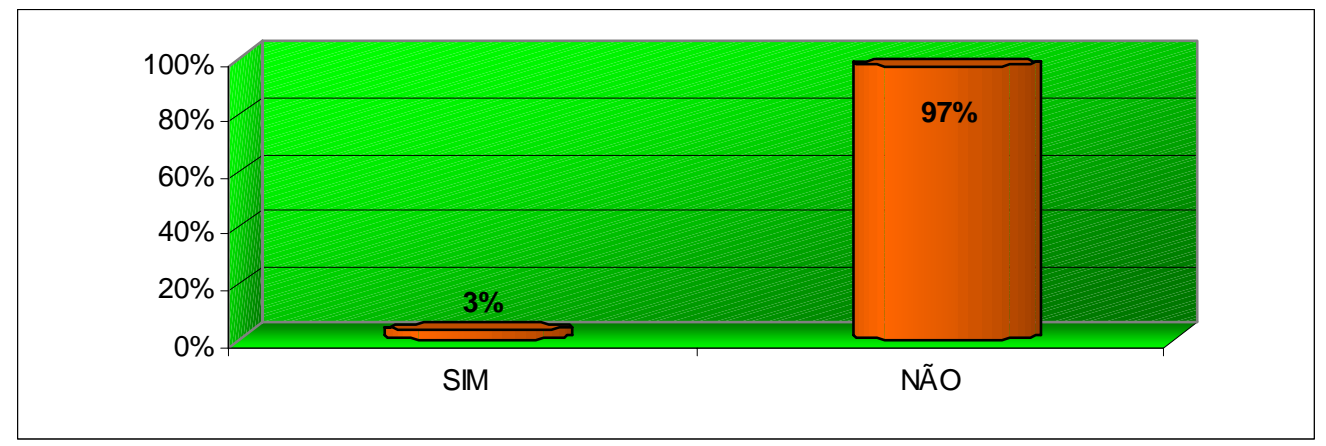

Pergunta 12 - Existe Sinalização Adequada no Poço Azul? (Interna e Externa)

Intento: conhecer a opinião do visitante quanto à infra-estrutura oferecida na Fazenda Poço Azul.

Resultado: verifica-se que $88 \%$ dos entrevistados consideram inadequada a sinalização interna e externa da Fazenda Poço Azul, havendo comentários de alguns (visitantes novos) que não sabiam quais os atrativos disponíveis e como chegar até as cachoeiras.

Figura 13 - O Visitante Considera a Sinalização (Interna e Externa) do Atrativo como Adequada

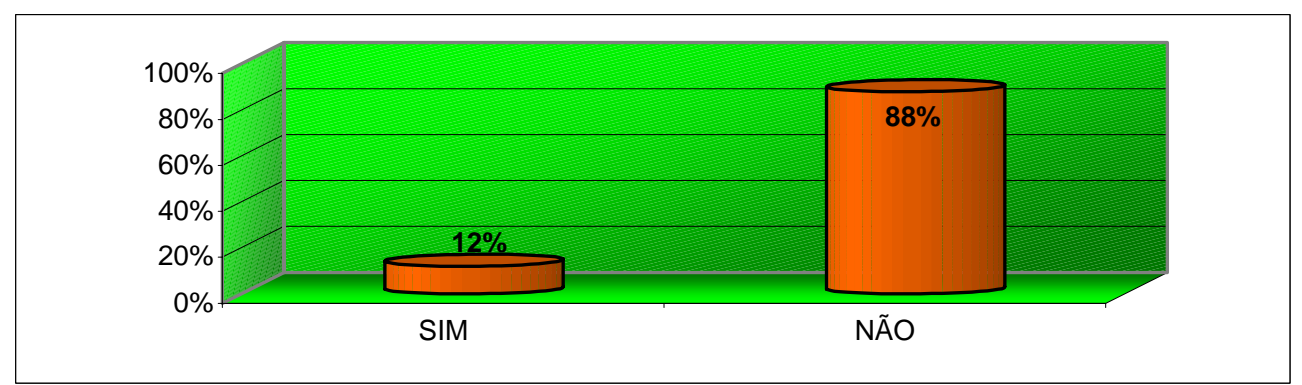

\section{Pergunta 13 - Quais as Deficiências Existentes no Poço Azul?}

Intento: conhecer a opinião do visitante quanto à infra-estrutura oferecida na Fazenda Poço Azul.

Resultado: verifica-se que 91\% dos entrevistados consideram inadequada a infra-estrutura oferecida, estando demonstrado no gráfico as deficiências enumeradas pelos visitantes - 
falta de banheiro, falta de segurança, falta de guias ou monitores, limpeza, inexistência de um bar, melhoria na estrada, falta de sinalização, falta de churrasqueiras, falta de normas de visitação.

Figura 14 - Deficiências do Atrativo Segundo Visitantes

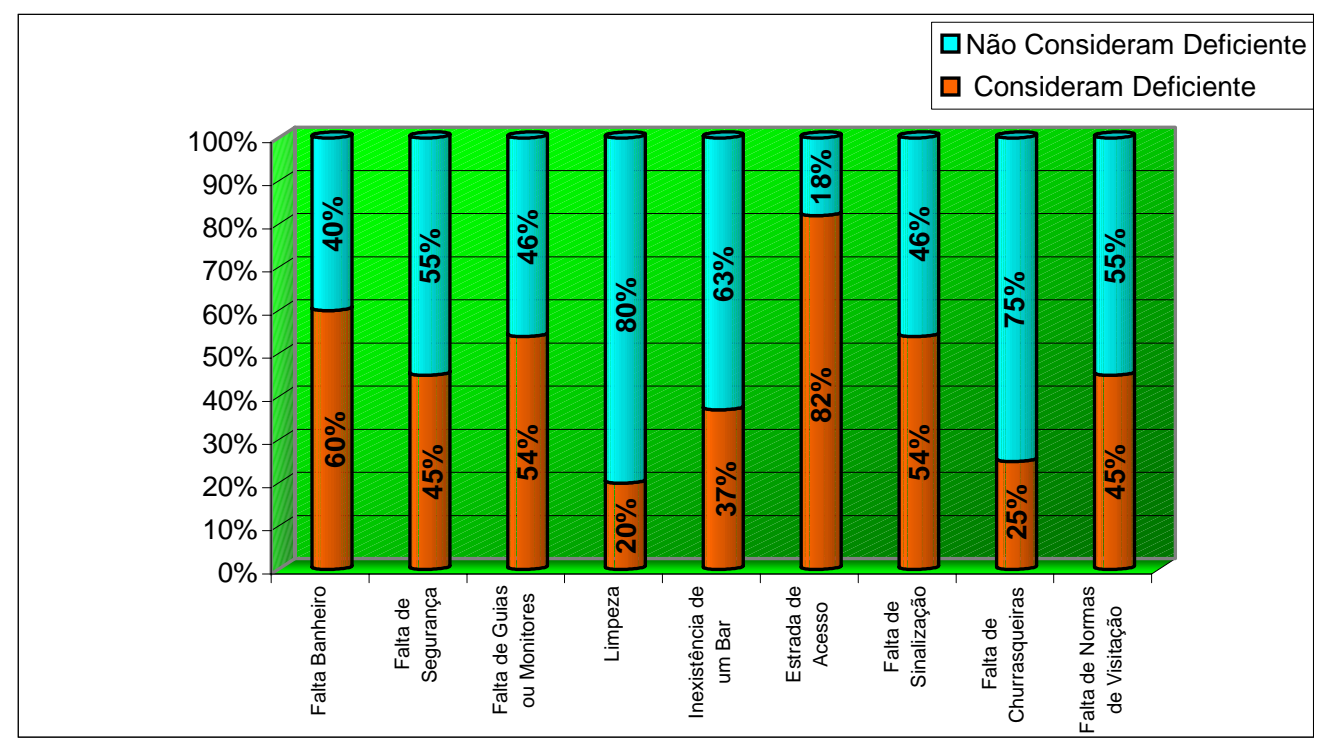

\section{Pergunta 14 - O Que Mais Gosta de Fazer no Poço Azul?}

Intento: detectar que tipo de atividades os visitantes gostam de realizar.

Resultado: houve um destaque de cada entrevistado por mais de uma opção, sendo que as mencionadas foram: realização de trilhas; esportes radicais; saltos das cachoeiras; observar a paisagem; ficar em contato com a natureza; fazer churrasco; ingerir bebidas alcoólicas; tomar banho de cachoeira; praticar mergulho e usar drogas. Constata-se que tomar banho nas cachoeiras é a atividade de maior interesse dos visitantes, sendo priorizado por 65\% dos entrevistados, seguido de 60\% que gostam de realizar trilhas. Observa-se que somente duas pessoas manifestaram atividades impróprias - uma em ingerir bebidas alcoólicas e outra em usar drogas. 
Figura 15 - O que o Visitante Gosta de Fazer no Atrativo

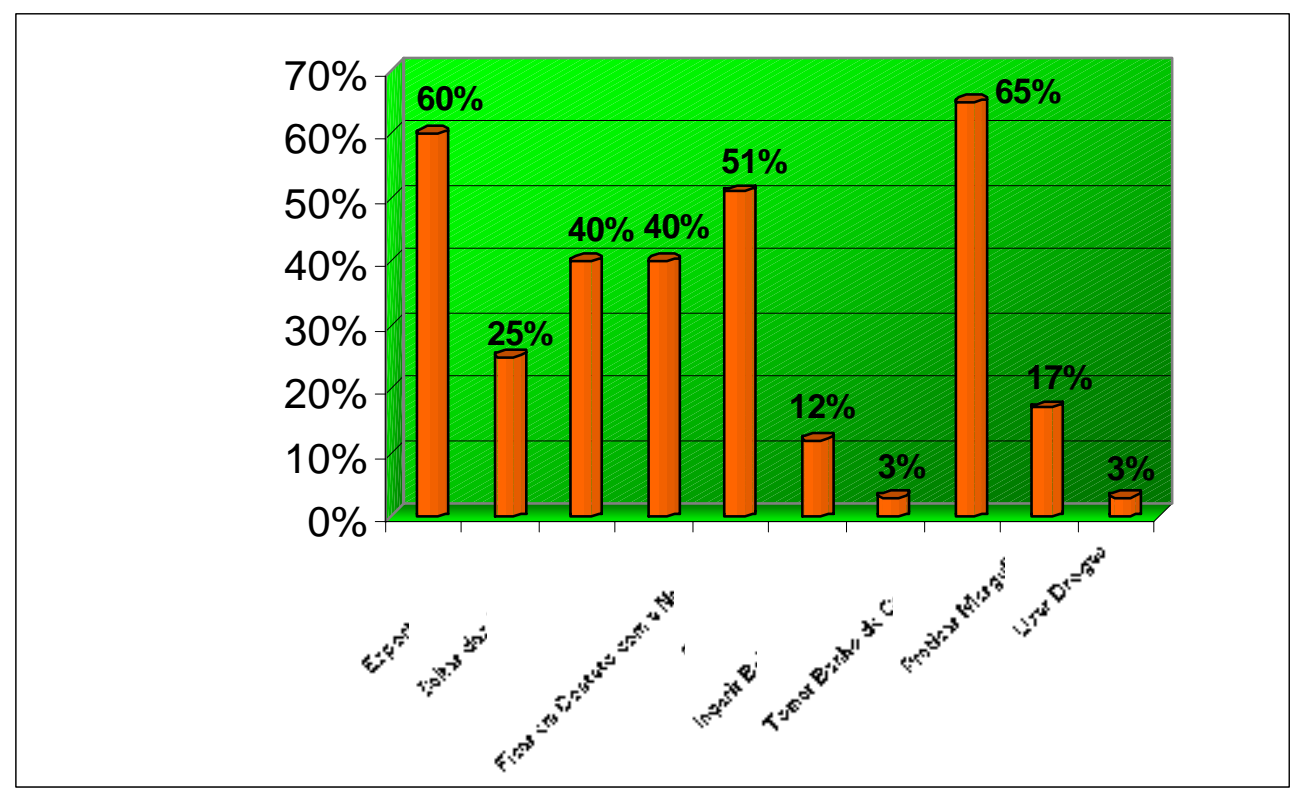

\section{Pergunta 15 - O Você Faz Com o Lixo que Produz?}

Intento: detectar o cuidado do visitante na utilização dos bens naturais.

Resultado: Dos entrevistados, 74\% declarou que junta o lixo e entrega na portaria da Fazenda, 23\% levam para casa e 3\% deixam na cachoeira. Mas, constatou-se “in loco” que os percentuais apurados não condiziam com a realidade encontrada no local - restos de comida, latas de bebidas, carvão queimado, sacos de lixo e outros.

Figura 16 - O que o Visitante Faz com o Lixo que Produz no Atrativo

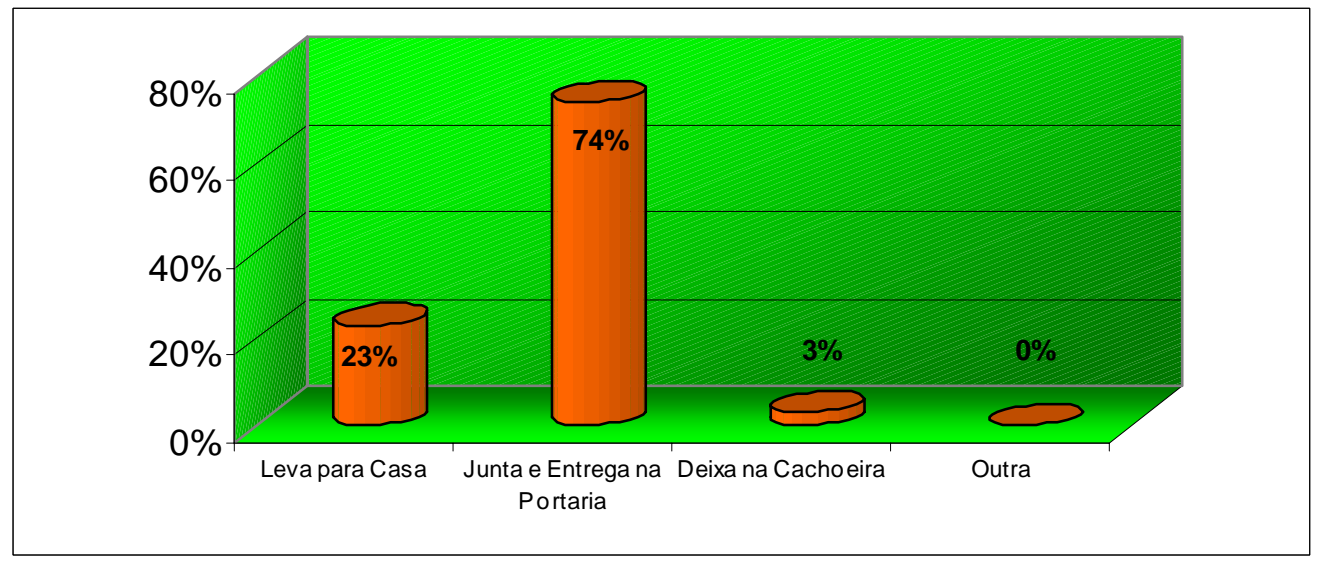




\section{Pergunta 16- A Forma Como são Utilizadas as Cachoeiras Causa Degradação ao Meio Ambiente?}

Intento: identificar o comprometimento dos visitantes com a preservação dos bens naturais.

Resultado: constatou-se que $68 \%$ dos entrevistados consideram que não causa degradação ao meio ambiente e $32 \%$ consideram que sim. Observa-se que os entrevistados que responderam que sim, estavam na faixa etária mais elevada, tendo maior consciência da responsabilidade na utilização do meio ambiente.

Figura 17 - Para o Visitante a Maneira Como são Utilizadas as Cachoeiras Causa Degradação ao Meio Ambiente

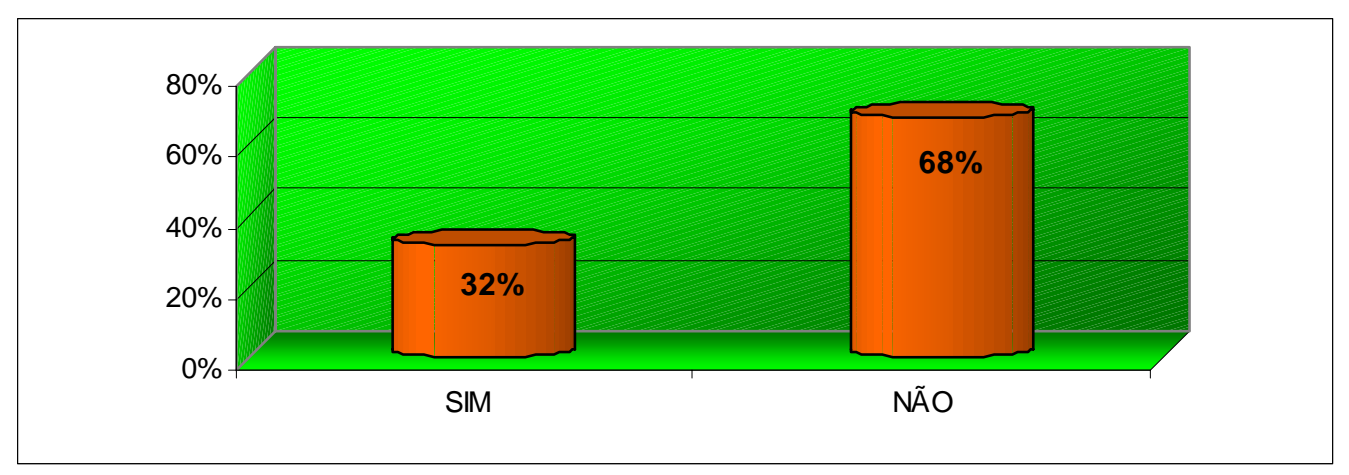

Pergunta 17 - Você se Importaria de Estacionar o Carro mais Longe para Minimizar o Impacto Provocado pela Estrada de Terra que dá Acesso a Cachoeira Da Gruta?

Intento: identificar o comprometimento dos visitantes com a preservação dos bens naturais.

Resultado: detectou-se que $80 \%$ dos entrevistados não se importariam de estacionar o carro mais longe.

Figura 18 - O Visitante se Importaria de Estacionar o Veículo mais Longe para Minimizar o Impacto ao Meio Natural

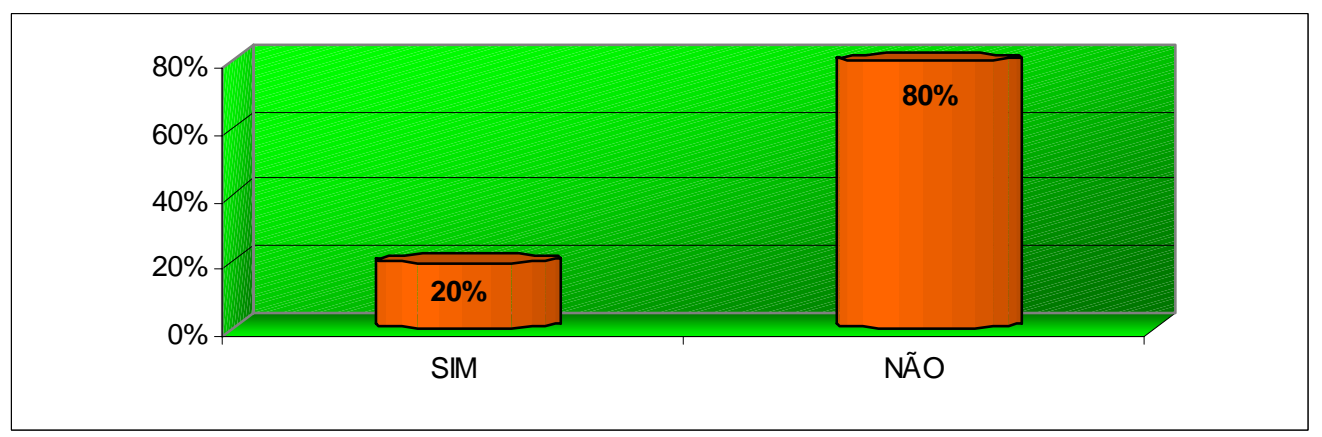




\section{Pergunta 18 - O Poço Azul Ficaria Melhor se Existisse um Número Pré- Determinado de Pessoas por Cachoeira?}

Intento: identificar o comprometimento dos visitantes com a preservação dos bens naturais.

Resultado: houve um percentual quase que equiparado entre as duas opções, 55\% consideraram que o número de pessoas por cachoeira não deveria ser pré-determinado e $45 \%$ consideraram que seriam muito melhor.

Figura 19 - Para o Visitante Seria Melhor se Existisse um Número Pré Determinado de Pessoas Por Cachoeira

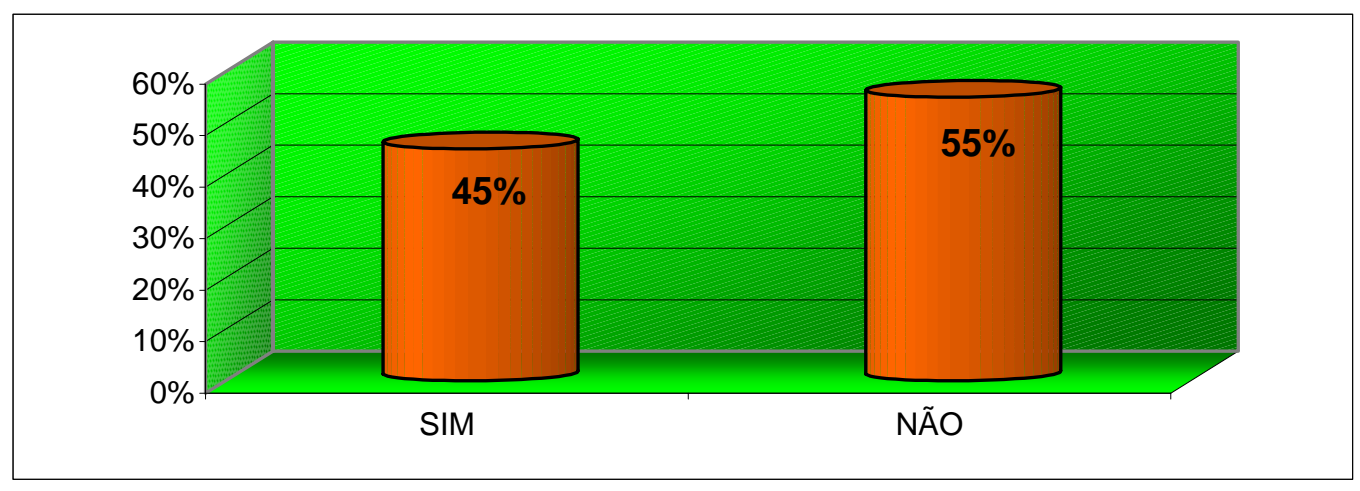

Pergunta 19 - Você Participaria de um Trabalho de Educação Ambiental (Palestras e Oficinas) no Poço Azul?

Intento: identificar o interesse dos visitantes em participar de oficinas e ou palestras sobre meio ambiente.

Resultado: detecta-se que $71 \%$ dos entrevistados demonstraram o interesse em participar de atividades educativas.

Figura 20 - Participaria de Trabalhos de Educação Ambiental (Palestras e Oficinas) no Atrativo?

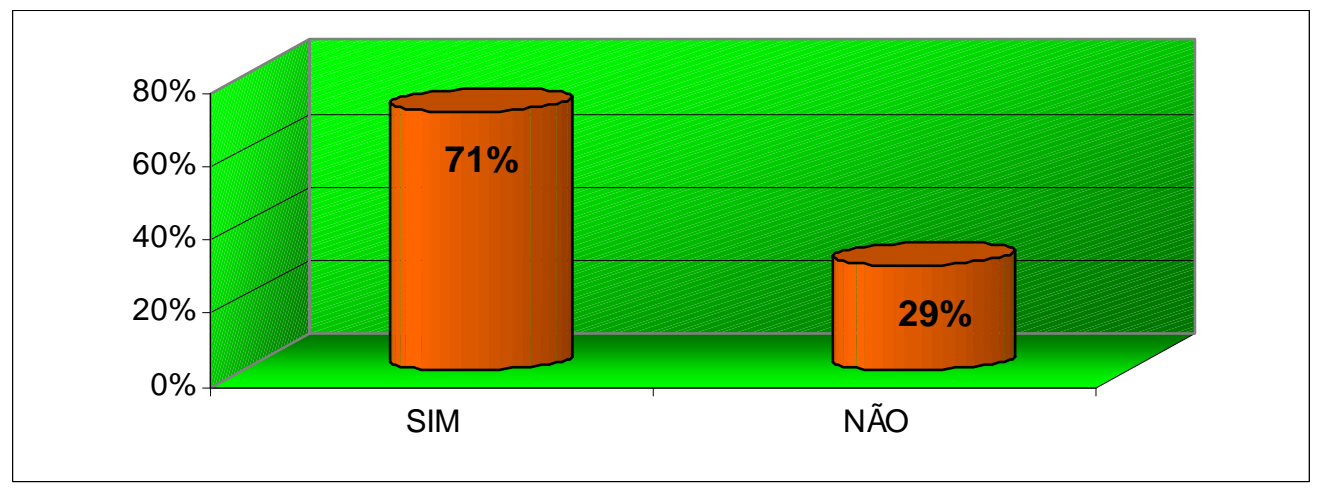


Pergunta 20 - Você é a Favor da Construção de um Local Específico para Churrasco?

Intento: identificar o interesse dos visitantes na criação de infra-estrutura para realização de atividades que são realizadas inadequadamente.

Resultado: detecta-se o interesse de 71\% dos entrevistados na utilização de área adequada para realização de churrasco.

Figura 21 - Deveria ser Construído Um Local Específico Para Churrasco?

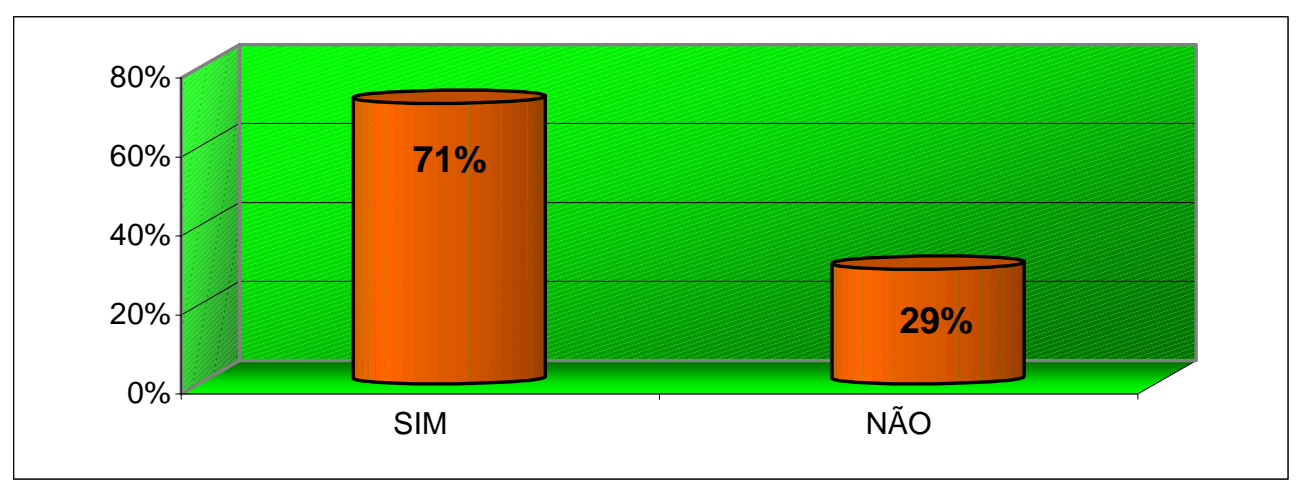

Pergunta 21 - Você Já se Machucou Saltando da Cachoeira ou Conhece Alguém que já?

Intento: detectar a necessidade de criação de infra-estrutura de segurança nas cachoeiras da Fazenda.

Resultado: constata-se que $71 \%$ dos entrevistados já se machucaram ou conhecem alguém que já se machucou saltando das cachoeiras.

Figura 22 - Você Já se Machucou Saltando da Cachoeira ou conhece alguém que já?

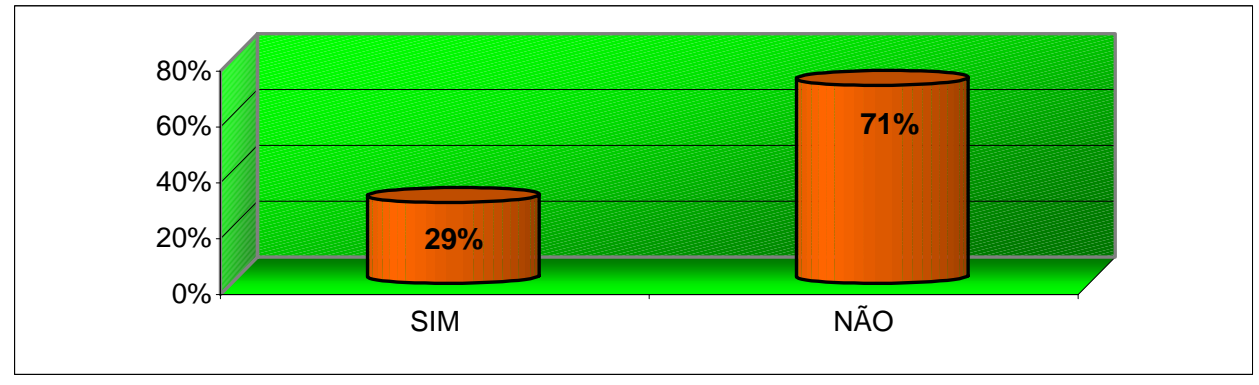


Pergunta 22 - Você Participaria de Aulas de Rapel, Escalada, Tirolesa ou Mergulho?

Intento: identificar o interesse dos visitantes em participar de aulas de maneira a poder sugerir o desenvolvimento de cursos específicos.

Resultado: detecta-se que $71 \%$ dos entrevistados possuem interesse em participar de aulas de rapel, escalada, tirolesa ou mergulho.

Figura 23 - Você Participaria de Aulas de Rapel, Escalada, Tirolesa ou Mergulho?

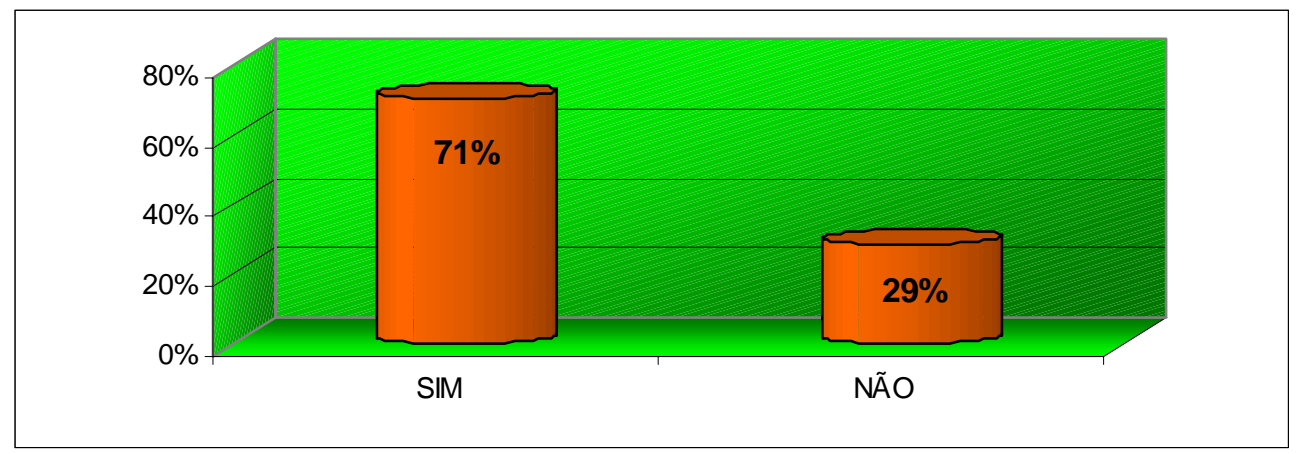

Pergunta 23 - A Obrigatoriedade para se Entrar na Fazenda Poço Azul de Guias Especializados que Forneçam Informações Sobre a Ecologia do Local e Fiscalizem o Respeito às Normas de Visitação, Minimizaria o Impacto do Visitante Sobre o Meio Ambiente?

Intento: identificar o interesse dos visitantes em obter informações sobre atrativo, detectar o cuidado do visitante na utilização dos bens naturais.

Resultado: detectou-se que $80 \%$ dos entrevistados afirmam que a obrigatoriedade para se entrar na Fazenda Poço Azul - DF de guias especializados que possam fornecer informações sobre a ecologia local e ao mesmo tempo fiscalizarem o respeito às normas de visitação, minimizaria os impactos dos visitantes sobre o meio ambiente. 
Figura 24 - A Obrigatoriedade de Guias Especializados para se Entrar na Fazenda Minimizaria o Impacto dos Turistas sobre o Meio Ambiente?

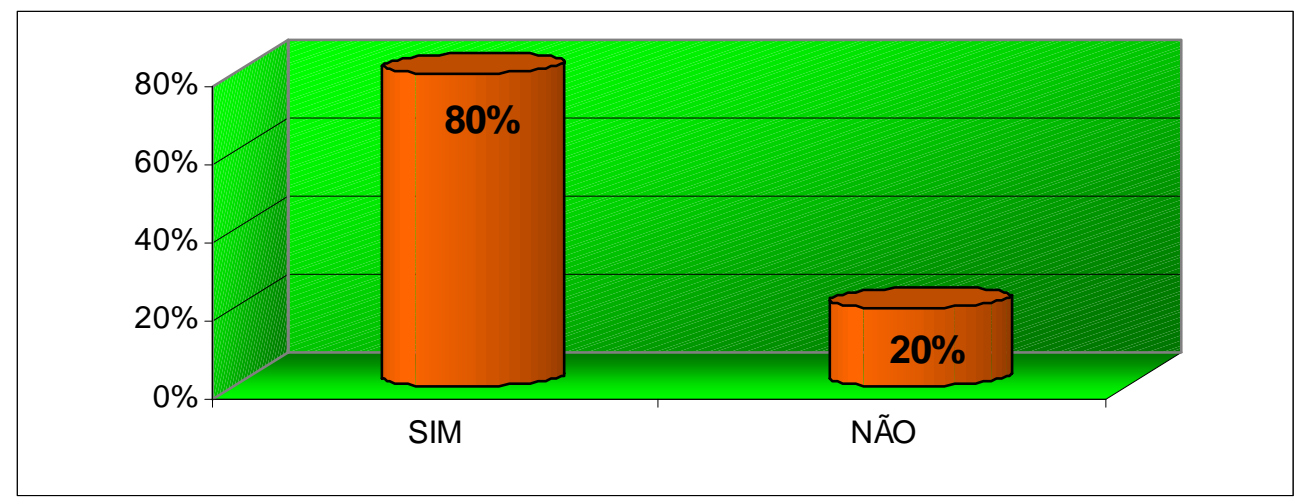

\section{Pergunta 24 - Você Já Foi Vítima de Assalto ou Furto Dentro do Atrativo?}

Intento: Identificar as condições de segurança do atrativo.

Resultado: constata-se que $15 \%$ dos entrevistados já sofreu furto no atrativo, percentual razoavelmente significativo que demonstra a necessidade de investimentos na segurança dos visitantes.

Figura 25 - Você Já Foi Vítima de Assalto ou Furto Dentro do Atrativo?

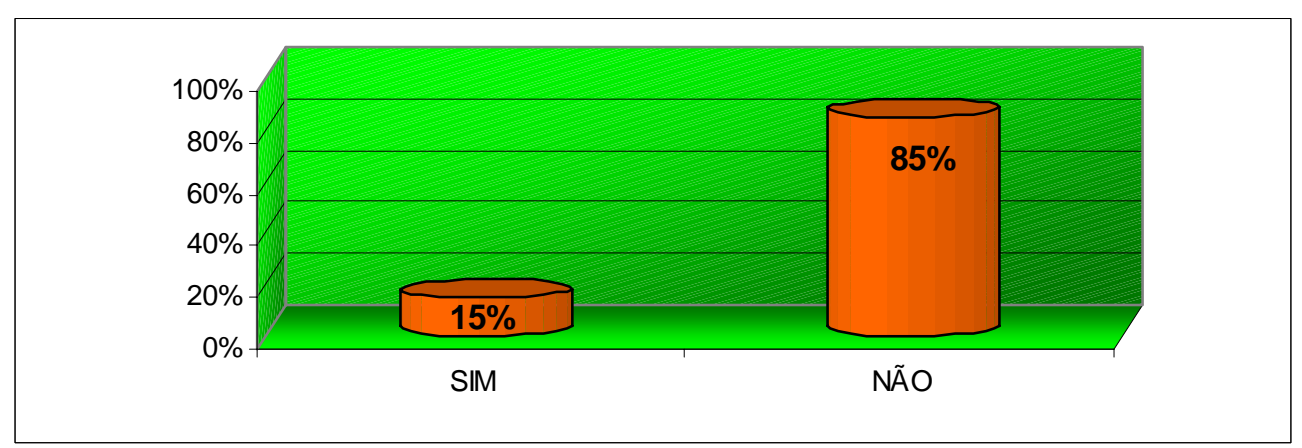

Pergunta 25 - Qual Nível de Satisfação do Visitante com a Infra-Estrutura Existente no Atrativo?

Intento: Identificar o nível de satisfação do visitante. 
Resultado: detecta-se que somente $5 \%$ dos entrevistados consideram ótima a infraestrutura existente, 35\% consideram boa, 35\% consideram regular, $14 \%$ ruim e $11 \%$ como sendo péssima.

Figura 26 - Qual o Nível de Satisfação que Você Tem com a Infra-Estrutura do Poço Azul?

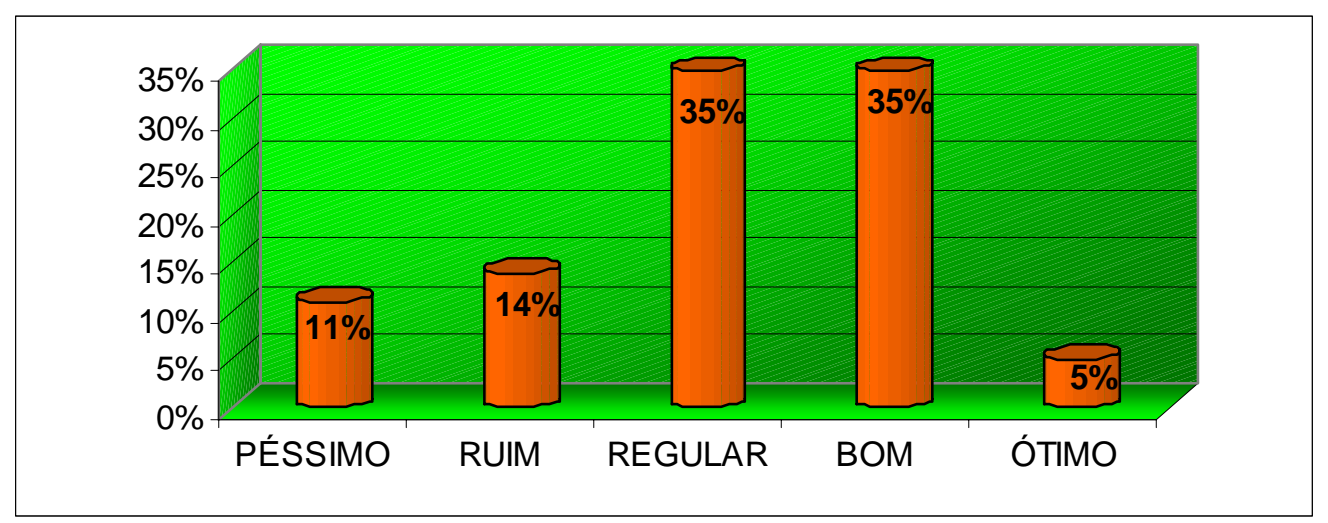

\section{Pergunta 26 - Qual Nível de Satisfação do Visitante com os Serviços} Disponibilizados pela Fazenda Poço Azul?

Intento: Identificar o nível de satisfação do visitante.

Resultado: verifica-se que apenas 3\% dos entrevistados consideram seu nível de satisfação com os serviços do atrativo como sendo ótimo, 20\% como bom, 25\% como regular, 32\% como ruim e $20 \%$ como péssimo. Portanto, a maioria dos entrevistados (77\%) estava insatisfeito com os serviços disponibilizados no atrativo.

Figura 27 - Qual o Nível de Satisfação que Você Tem com os Serviços Disponibilizados no Poço Azul?

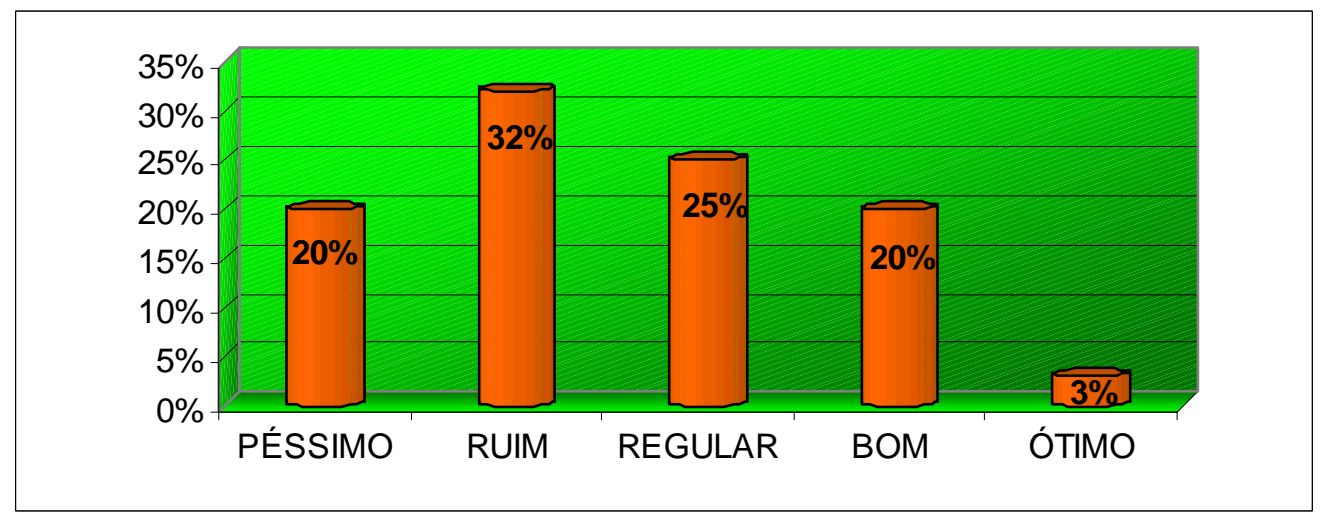


Pergunta 27 - Qual Nível de Satisfação do Visitante com os Recursos Naturais Existentes na Fazenda Poço Azul?

Intento: Identificar o nível de satisfação do visitante.

Resultado: constatou-se que $48 \%$ dos entrevistados considera os recursos naturais do atrativo como sendo ótimo, 43\% como sendo bom e 9\% como sendo regular. Portanto, a maioria dos entrevistados (91\%) se encontram satisfeitos com os recursos naturais disponíveis no atrativo.

Figura 28 - Qual o Nível de Satisfação que Você Tem com os Recursos Naturais Existentes na Fazenda Poço Azul - DF?

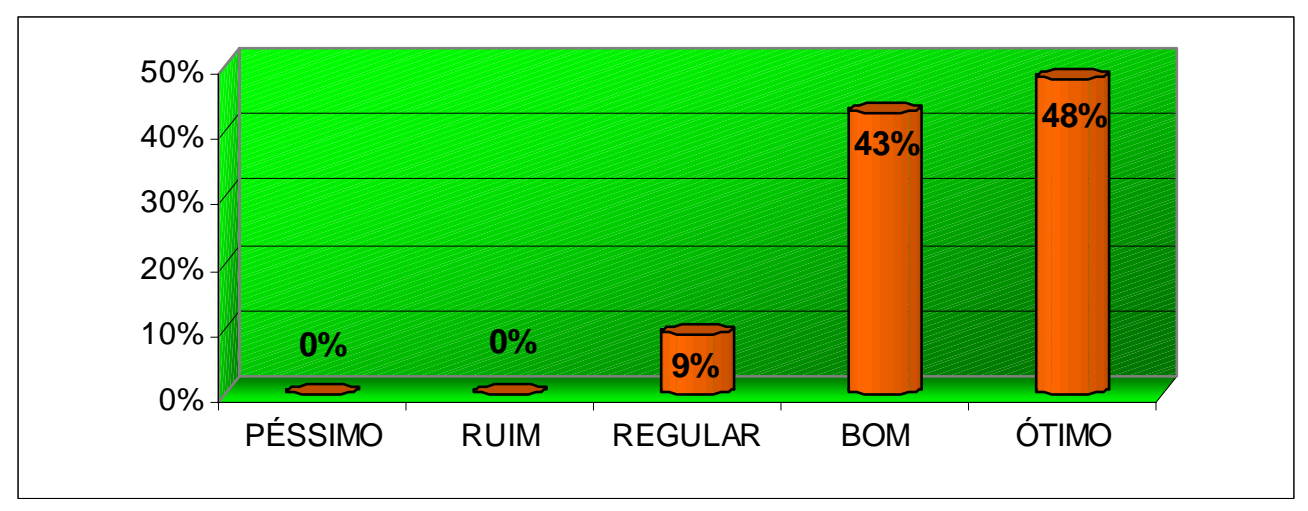

\section{3- PROPOSTAS PARA O DESENVOLVIMENTO DO ECOTURÍSMO NA FAZENDA POÇO AZUL - DF}

Os dados levantados com a pesquisa realizada junto aos visitantes da Fazenda Poço Azul - DF e as observações feitas, permitiram detectar a necessidade de adequação para o desenvolvimento do Ecoturismo no referido Atrativo.

Baseado nos estudos realizados, foram desenvolvidas propostas que buscam sugerir ações para que a atividade turística no atrativo possa ocorrer de maneira menos impactante e mais sustentável. 


\subsection{1-Acesso:}

- Buscar articulação e desenvolver parceria com a administração de Brazlândia para o reparo e manutenção das estradas que permitem o acesso principalmente à parte de terra da DF 001 que se encontra em péssimas condições, sendo uma estrada de grande importância, pois é uma rodovia bastante utilizada por caminhões de carga e por turistas que vão visitar atrativos da região.

\subsection{2-Taxa de Visitação:}

- Sugere-se que seja implementada uma taxa diferenciada para grupos e para agências de viagens;

- Isentar da taxa de visitação os profissionais que trabalham com turismo como Guias de Turismo e Agentes de Viagens, devido ao fato de serem parceiros para o incremento e propulsão do empreendimento.

\subsection{3-Capacidade de Carga}

- Deverá ser definida a capacidade de carga total que a Fazenda pode receber, a capacidade de carga de cada atrativo e a capacidade de carga de cada um dos percursos e roteiros que forem elaborados. Para tanto, faz-se necessária a utilização de apoio técnico especializado.

\subsection{4- Normas de Visitação}

- Obrigatoriedade de um guia de turismo para a entrada na fazenda;

- Obrigatoriedade de participação em oficinas ou palestras que envolvam o processo de educação ambiental;

- Proibir a entrada de veículos nas trilhas; 
- Estipular os locais em que são permitidos saltos nas cachoeiras;

- Proibir jogar lixo nas trilhas ou nos atrativos;

- A prática de esportes radicais somente poderá ser realizada mediante a assinatura de um termo de responsabilidade na qual o praticante assume os riscos provenientes da prática desses esportes;

- Proibir a entrada de animais domésticos na Fazenda;

- Proibir a retirada de pedras, plantas, flores, frutos e outros recursos naturais das trilhas e dos atrativos;

- Proibir a realização de churrascos fora da área determinada para tal.

\subsection{5-Sinalização}

- Sinalização interna:

- Implementação de placas de sinalização em todas as trilhas, inclusive nas bifurcações existentes em seu percurso, indicando o nome da trilha, o nome do atrativo ao qual se destina, a distância de trilha, o grau de dificuldade e o mapa do percurso a ser seguido;

- Sinalização externa:

- Manter a sinalização já existente;

- Articular com a Secretaria de Turismo de Brasília e com a Administração de Brazlândia para implementação de placas indicativas para orientar o turista quanto ao acesso à Fazenda Poço Azul; 


\subsection{6- Sistema de Limpeza}

- Com vistas a fazer uma limpeza geral, sugere-se o envolvimento de crianças, adolescentes e jovens de escolas da comunidade, realizando um evento “ $\mathrm{O} 1^{\circ} \mathrm{Dia}$ Ecológico Poço Azul”, ou uma gincana, ou outras atividades, que permitam desenvolver um mutirão para recolher o maior número possível de lixo existente;

- Após essa grande limpeza, as ações de gestão deverão estar voltadas mais para fiscalização, podendo ter maior eficiência se forem disponibilizados sacos de lixo individuais para cada visitante;

- Deve-se disponibilizar uma pessoa para limpeza do banheiro pelo menos 01 vez ao dia durante a semana e 04 vezes ao dia nos finais de semana.

\subsection{7- Serviço de Condução de Visitantes}

- Pelo fato de não existir nenhum guia especializado que atue na Fazenda Poço Azul, existe a necessidade de se realizar uma análise para se definir a quantidade de guias necessários para atender a demanda inicial da Fazenda, levando em consideração a capacidade de carga;

- Definida a quantidade de guias necessários, deve ser iniciado um processo de recrutamento e a seleção de pessoas junto à própria comunidade ou região, para trabalharem como guias na Fazenda Poço Azul, buscando inserir a população local no processo de desenvolvimento turístico no atrativo;

- Após serem selecionados, os guias deverão receber um treinamento específico para atuarem na Fazenda, devendo esse treinamento ser elaborado e ministrado por instituições que possuam capacidade técnica necessária. Esse treinamento deverá abordar assuntos como reconhecimento de trilhas, ecologia, fauna e flora local, atendimento ao público, educação ambiental, técnicas de orientação, primeiros socorros entre outros; 
- Os guias devem ser formados e preparados de modo a se sentirem e serem responsabilizados por seus atos e atitudes.

\subsection{8- Educação Ambiental}

- Os visitantes devem receber orientações sobre como utilizar os atrativos disponíveis de maneira adequada e respeitando os recursos naturais;

- Indica-se a disponibilização para os guias de um manual contendo informações básicas sobre os pontos significativos para o desenvolvimento de uma consciência ambiental;

- No caso de visitação de escolas, deve ser elaborado um roteiro que permita o desenvolvimento de um circuito pedagógico, ou seja, que os visitantes vivenciem todos os aspectos referentes à Fazenda interligando com os conteúdos aprendidos no ensino formal. Essa sugestão pode ser desenvolvida, também, no cotidiano, desenvolvendo atividades com crianças visitantes no atrativo.

\subsection{9-Trilhas}

- Realizar um inventário ou um levantamento minucioso de todas as trilhas existentes e suas bifurcações, identificando distâncias e locais de perigo, resultando na elaboração de um mapa da Fazenda com todas essas informações;

- Baseados no mapa devem ser elaborados três tipos de percurso de trilhas e atrativos, sendo um percurso leve (com trilhas de menor distância, menor grau de dificuldade, que levem a visitação de atrativos mais próximos); um percurso moderado (com trilhas de média distância, que apresentem um grau de dificuldade médio que levem a visitação de atrativos); e um percurso pesado (com trilhas longas, com alto grau de dificuldade, que apresentem maior duração e que levem a visitação de atrativos mais distantes); 
- Esses percursos devem possuir roteiros especificando tempo total de visitação, tempo de permanência nas cachoeiras, tempo médio de trilha, locais onde podem ser feitas as paradas para descanso (caso necessário), quais atrativos serão visitados e quais conteúdos podem ser trabalhados junto à ecologia local;

- Com a definição dos percursos e trilhas que podem ser utilizados na Fazenda, pode ser elaborado um plano de recuperação e fechamento das trilhas que não serão utilizadas. É de extrema importância que a elaboração desse processo seja realizada com apoio técnico especializado;

- $\quad$ Deve ser proibida a entrada de carro nas trilhas;

- É de extrema necessidade e urgência que as trilhas que permitiam a passagem de carros sejam interditadas, sendo elaborado um plano de recuperação do ambiente degradado e minimização dos impactos já provocados;

- Nos locais de perigo indicados no inventário devem ser instalados equipamentos que possam garantir a segurança dos visitantes.

\subsubsection{0-Equipamentos}

- Equipamentos de Higiene:

- Devem ser instalados banheiros que possuam boas condições de uso e possibilitem a utilização pelos visitantes.

- Equipamentos de Saúde:

- Compra e elaboração de um "kit” de primeiros socorros para todos os Guias da Fazenda;

- Compra de equipamentos de socorro mais caros como macas, colares cervicais e outros que sejam indicados pelo corpo de bombeiros; 
- Capacitação e treinamento do administrador quanto à utilização desses equipamentos e realização de primeiros socorros.

\subsubsection{1-Alimentos e Bebidas}

- Desenvolver parceria para obtenção de alimentos com propriedades vizinhas ou com pessoas da comunidade que produzam frutas, pão, queijo, requeijão, leite, presunto, verduras, biscoitos, bolos e outros alimentos que possam ser feitos artesanalmente (mantendo o padrão de qualidade), tornando-os fornecedores. Com isso o desenvolvimento do turismo na Fazenda Poço Azul contribuirá para o desenvolvimento da comunidade local;

- Definir um local para instalação da lanchonete que poderá ser administrada pela própria Fazenda ou ser terceirizada;

\subsubsection{2-Segurança}

- Definir normas de visitação que devem ser rigorosamente seguidas e a fiscalização da utilização dos atrativos permitirá uma maior segurança aos usuários;

- Com a proibição de entrada de carros nas trilhas, deverá ser construído um estacionamento próximo à recepção, diminuindo a possibilidade de furtos e assaltos;

- Para garantir a segurança dos visitantes na utilização das trilhas, devem ser instalados corrimãos ou outros equipamentos nos locais de maior perigo;

- Disponibilizar equipamentos de saúde que possam garantir os primeiros socorros caso haja algum acidente; 
- Implantar um sistema de comunicação entre os guias e a administração por meio de walk-talk ou talk-abaut, permitindo uma rápida comunicação e atendimento a qualquer situação emergencial.

\subsubsection{3-Marketing}

- Deve ser elaborado e aplicado um plano de Marketing;

- Buscar desenvolver parcerias ou projetos pedagógicos com escolas com intuito de minimizar a sazonalidade nos dias de semana;

- Desenvolver parcerias com operadoras e agências de viagens.

\subsubsection{4-Administração}

- Contratação ou realização de parceria com um turismólogo ou técnico em turismo para que possa orientar e acompanhar o processo de administração, gestão e planejamento turístico de forma especializada;

- O administrador deve ser preparado para atender as exigências de sustentabilidade das atividades turísticas desenvolvidas na Fazenda Poço Azul;

\subsubsection{5-Centro de Atendimento ao Turista}

- A implementação de um Centro de Atendimento ao Turista pode ocorrer na própria recepção da Fazenda, onde podem ser comercializados produtos do artesanato local, camisetas e outros itens, além da disponibilização de informações sobre ecologia, história ou educação ambiental;

\subsubsection{6-Monitoramento e Acompanhamento}

- O acompanhamento dos serviços e da infra-estrutura disponibilizada pela Fazenda deverá ser realizado por intermédio de questionários de avaliação (a serem 
elaborados) que serão disponibilizados aos visitantes no final das visitas com intuito de averiguar o nível de satisfação destes com os serviços oferecidos;

- O acompanhamento ambiental deverá ser realizado por visita de um técnico especializado pelo menos duas vezes ao ano, procedendo dessa visita um relatório que indicará os impactos positivos e negativos provocados pelo desenvolvimento da atividade turística no atrativo;

- Devem ser realizadas avaliações periódicas para reprogramação das metas, estratégias e tomadas de decisões. 


\section{CONSIDERAÇÕES FINAIS}

O atrativo natural Fazenda Poço Azul, indiscutivelmente, possui um potencial extraordinário para o desenvolvimento do ecoturismo, tendo seus atrativos naturais com um beleza admirável. Mas detectou-se que sua utilização é feita de maneira “amadora”, sendo visível o processo de degradação acelerado, podendo trazer, a longo prazo, impactos irreversíveis aos recursos naturais disponíveis.

O estudo e as constatações resultantes desta pesquisa permitem afirmar que o desenvolvimento da atividade turística na Fazenda Poço Azul é realizada de maneira insustentável, sendo explorada de forma desordenada e necessitando urgentemente do desenvolvimento de um Plano de Manejo e de Gestão Turística.

Se medidas e "atitudes" como as propostas neste trabalho forem adotadas os resultados podem levar ao desenvolvimento da comunidade local, a minimização dos impactos sobre o meio natural e ao aumento do retorno financeiro para o proprietário levando ao desenvolvimento da atividade turística no atrativo a ocorrer de forma sustentável. 


\section{REFERÊNCIA BILIOGRÁFICA}

- AlBERnAZ. Patrícia Cunha. O Ecoturismo como Instrumento de Conservação Ambiental e Viabilidade Econômica para RPPNs: Um Estudo de Caso no SVS Vagafogo. 2003

- ANDREAZZI, Suely. Ecoturismo Vira Mania Mundial. Jornal O Estado de São Paulo. São Paulo, 22 de outubro de 2003.

- BARROS II, Sívio de. Programa de Desenvolvimento de Pólo Ecoturístico. In: Anais do I Seminário de Ecoturismo do Distrito Federal, Entorno e Goiás. Brasília: SEBRAE/DF: SEBRAE/GO. Secretaria de Turismo do Distrito Federal, 1996.

- BARROS, Sílvio Magalhães e LA PENHA, Denise Hamu M. de, coord. Ecoturismo: Diretrizes para uma Política Nacional de Ecoturismo, "Conceituação", p. 19, Brasília, EMBRATUR, 1994.

- BEZERRA, Deise Maria Fernandes. Planejamento e Gestão em Turismo. São Paulo: Roca, 2003.

- BORGES, Marcos M. (2003). Levantamento do Pontecial Ecoturístico. In: Manual de Ecoturismo de Base Comunitária. Brasília, DF:WWF.

- Comissão Mundial de Meio Ambiente e Desenvolvimento - CMMAD. Relatório: Nosso Futuro Comum. 1991.

- Conselho Brasileiro para o Turismo Sustentável - CBTS. Princípios do Turismo Sustentável no Brasil. Versão 4.2 de outubro de 2001. Disponível na Internet em: <http://www.wwf.org.br/projetos/siteturismo_cbtsprincipios.htm>, acesso em: 25 de março de 2005.

- Diário Oficial da União - DOU de 28 de abril de 1999; Seção 1; pg 01.

- EDMIR, Kuazaqui. Marketing Turístico e de Hospitalidade: Fonte de empregabilidade e desenvolvimento para o Brasil. São Paulo: MAKRON Books, 2000.

- EMBRATUR. DIRETRIZES POLÍTICA NACIONAL DE ECOTURISMO. Grupo de Trabalho Interministerial, organizado pelo MINISTÉRIO DO MEIO AMBIENTE E DA AMAZÔNIA LEGAL e pelo MINISTÉRIO DA INDÚSTRIA, DO COMÉRCIO E DO TURISMO, 1994.

- HETZER, N. D. Environment, tourism, culture. LINKS, 1965. reeditado em Ecosphere,1970.

- IGNARRA, R. (s.d). Planejamento Turístico Municipal, um modelo brasileiro. São Paulo: CTI. 
- IRVING, Marta \& AZEVEDO, Julia. Turismo: o desafio da sustentabilidade. São Paulo: Futura. 2002.

- IUCN, UNEP e WWF. Caring for the Earth: a Stratey for Sustainable Living. 1991 apud adaptação disponível na internet em: $<$ http://planeta.terra.com.br/lazer/staruck/sustentavel.htm>, acesso em 25 de mar. de 2005.

- LOZANO, Romero e FERRER, Sebastián. El Planeamiento de la Educación.ILPES, Santiago de Chile.1978.

- Ministério do Meio Ambiente - MMA: Centro de Desenvolvimento Sustentável CDS da Universidade de Brasília - UnB. Ciência \& Tecnologia para o Desenvolvimento Sustentável. Brasília, 2000, pág.42.

- NORGAARD. R. B. O Crescimento da economia global de trocas e a perda da diversidade biológica. In: Biodiversidade. Rio de Janeiro: Nova Fronteira, 1997 pág. 261.

- Organização Mundial do Turismo - OMT. Guia de desenvolvimento do turismo sustentável. Porto Alegre: Bookman, 2003. 168p.

- $\quad$ PETROCCHI, M. 2001. Gestão de Pólos Ecoturismo.São Paulo: Futura. 457 p.

- RUSCHMANN, D V. M. 1997. Turismo e Planejamento Sustentável. Campinas: Papirus.

- SAlVATI, Sérgio S. (2003). Planejamento do Ecoturismo. In: Manual de Ecoturismo de base Comunitária. Brasília,DF:WWF.

- SOUZA, Paulo Roberto P. Além do Estado: os papeis da iniciativa privada e do terceiro setor na implementação e manejo das unidades de conservação. In: MILANO, Miguel S. (org.). Unidades de Conservação: atualidades e tendências. Curitiba: Fundação Boticário de proteção à natureza, 2002.

- TIES - International Ecotourism Society. Ecotourism Statistical Fact Sheet.2000. Disponível na Internet em: <www.ecotourism.org>, acessado em 23 de março de 2005.

- TRIGO, Luiz Gonzaga Godoi. Turismo e Desenvolvimento Sustentável. In: FIGUEIREDO, Silvio Lima (org.). O Ecoturismo e a Questão Ambiental na Amazônia. Belém:UFPA/NAEA, 1999.

- YÁZIGI, Eduardo. Ecoturismo: uma doce ilusão. Cap.VI. P 115 a 138. 


\section{ANEXO A \\ PESQUISA DE OPINIÃO - VISITANTE POÇO AZUL}

1- Qual o local de moradia:

UF:

2- Qual sua idade:

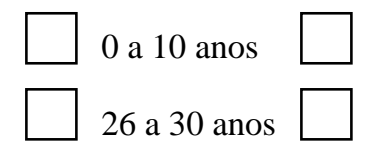

11 a 15 anos

$\square 16$ a 20 anos

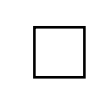

21 a 25 anos

3- Escolaridade:
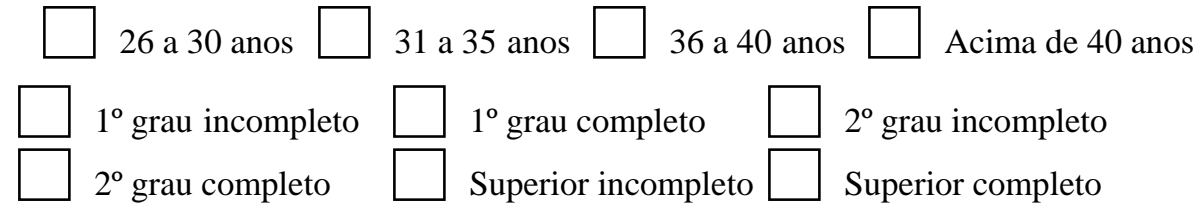

4- Profissão:

5- Renda mensal: Sem renda 01 a 500 reais 501 a 1000 reais 1001 a 1500 reais

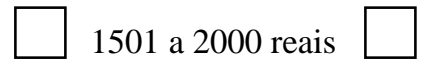
2001 a 3000 reais Acima de 3000 reais

6- É a primeira vez que visita o Poço Azul ou já visitou em outras ocasiões?
$\square$ Primeira vez $\square$ Duas vezes
De 3 a 5 vezes
De 6 a 10 vezes
Mais de 10 vezes

7- Costuma vir acompanhado de quantas pessoas?
$\square$ Sozinho De 1 pessoa
De 2 a 5 pessoas Acima de 5 pessoas

8- Veio por intermédio de:

9- Qual meio de transporte utilizado?

Bicicleta Outros:

10- Como ficou sabendo do Poço Azul?

$\square$ Amigo Folders Anuncio em revistas ou jornais Agência de viagens Guia ou monitor de turismo Outra:

11- O acesso ao Poço Azul, está em boas condições:

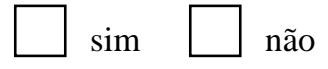

12- Existe sinalização adequada no Poço Azul:

Sinalização Interna: $\square \operatorname{sim} \square$ não Sinalização Externa (no acesso): $\operatorname{sim} \square$ não 
13- Se não, quais as deficiências?

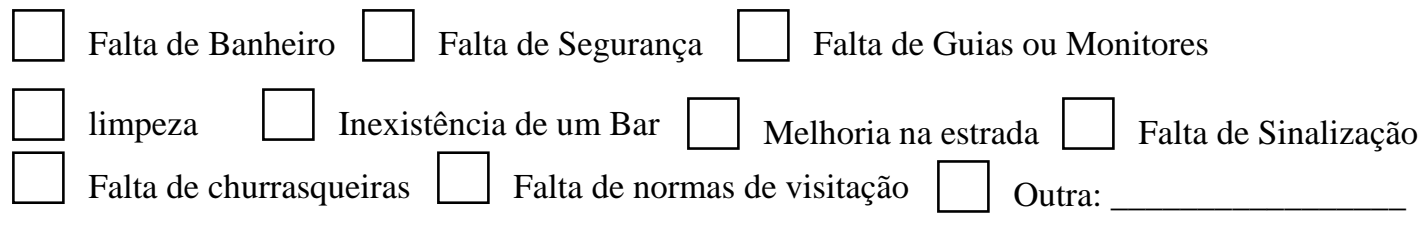

14- O que mais gosta de fazer no Poço Azul?

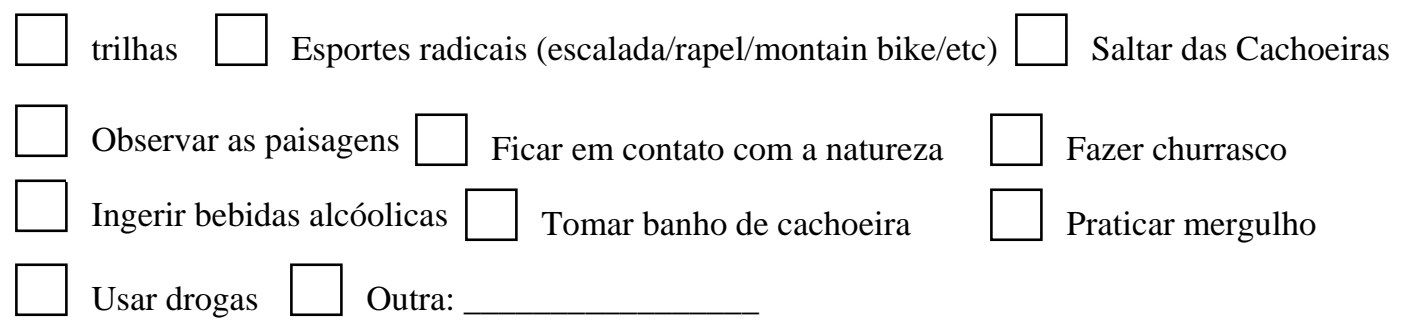

15- O você faz com o lixo que produz?

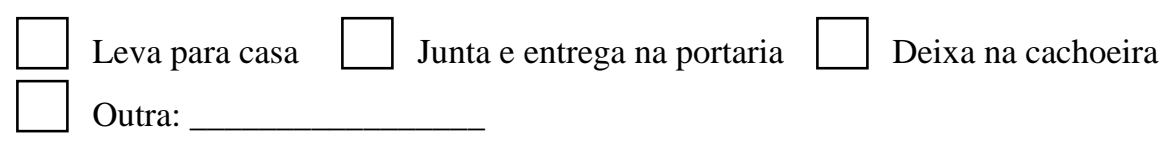

16- A forma como são utilizadas as cachoeiras causa degradação ao meio ambiente?<smiles>[SnH2]C1CCC1</smiles>

17- Você se importaria de estacionar o carro mais longe da cachoeira para minimizar o impacto provocado pela estrada de terra que dá acesso a cachoeira da gruta?

$\square \operatorname{sim} \square$ não

18- O Poço Azul ficaria melhor se existisse um número pré-determinado de pessoas por cachoeira? $\square \operatorname{sim} \square$ não

19- Você participaria de um trabalho de educação ambiental (palestras e oficinas) no Poço Azul? $\operatorname{sim} \square$ não

20- Você é a favor da construção de um lugar específico para churrasco?

$\square \operatorname{sim} \square$ não

21- Você já se machucou saltando na cachoeira ou conhece alguém que já?<smiles>C1CC([SnH2]C2CCC2)C1</smiles>

22- Você participaria de aulas de rapel, escalada, tirolesa ou mergulho se fossem disponibilizadas para os visitantes do Poço Azul?

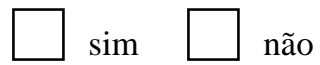


23- A obrigatoriedade para se entrar na fazenda de guias especializados que forneçam informações sobre a ecologia do local e fiscalizem o respeito às normas de visitação, minimizaria o impacto do visitante sobre o meio ambiente? $\square$ sim $\square$ não 24- Você já foi vítima de assalto ou furto dentro da propriedade poço azul?

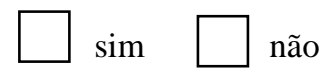

25- Qual o nível de satisfação que você tem com a infra-estrutura do poço azul?

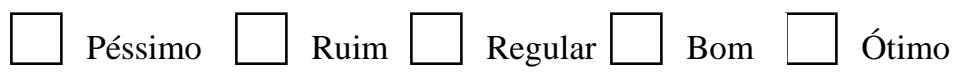

26- Qual o nível de satisfação que você tem com os serviços disponibilizados do poço azul? $\square$ Péssimo $\square$ Ruim $\square$ Regular $\square$ Bom $\square$ Ótimo

27- Qual o nível de satisfação que você tem com os atrativos naturais do poço azul?

$\square$ Péssimo $\square$ Ruim $\square$ Regular $\square$ Bom $\square$ Ótimo 
ANEXO B

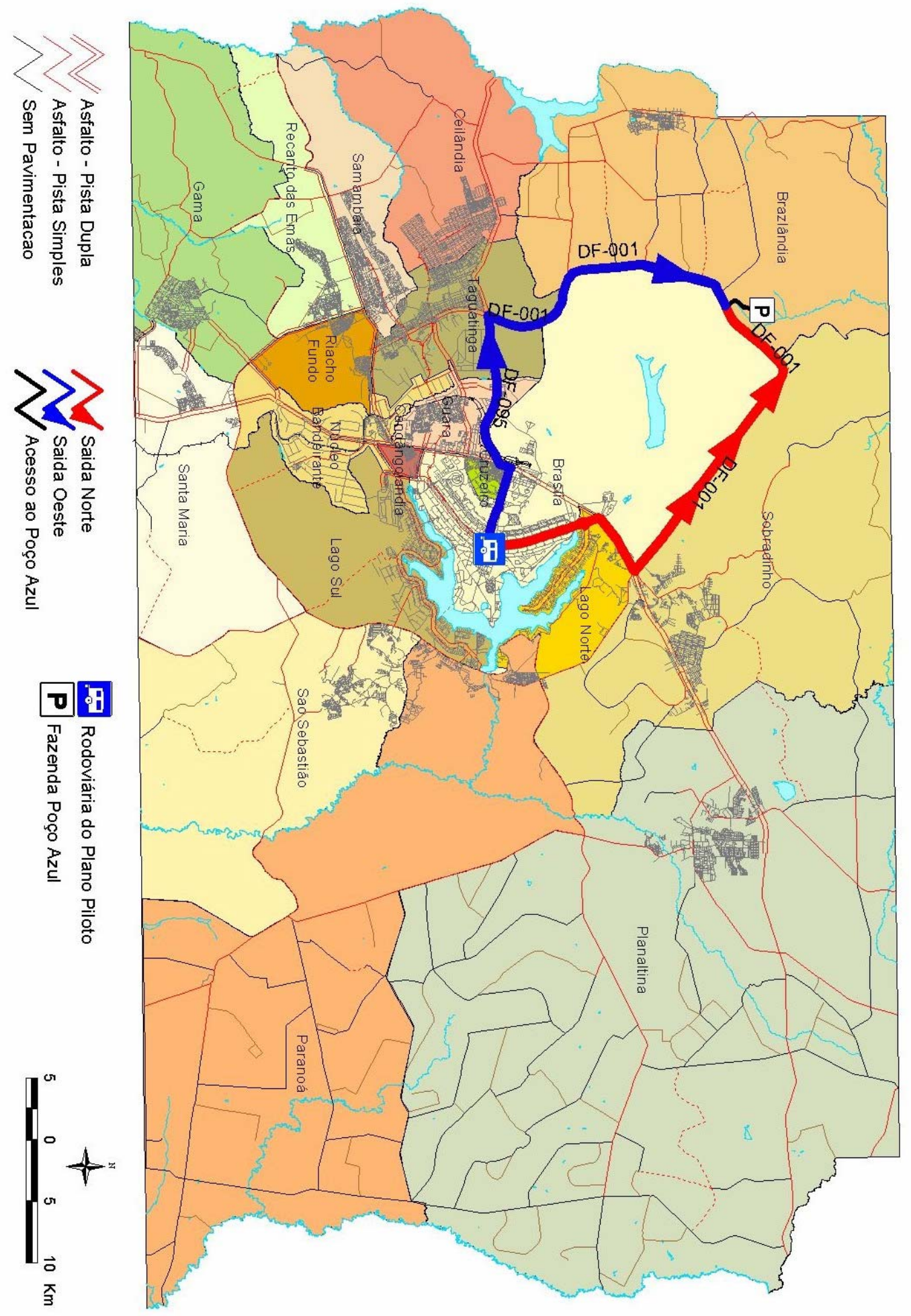

